\title{
Basal sliding and plastic deformation of a slow, reactivated landslide in New Zealand
}

\author{
C.I. Massey [a], D.N. Petley [b], M.J. McSaveney [a], G. Archibald [a] \\ [a] GNS Science, Avalon, Lower Hutt, New Zealand \\ [b] The University of East Anglia, Norwich, UK
}

\begin{abstract}
The Taihape landslide is a large, deep-seated, translational rockslide in central North Island of New Zealand, one of over 7000 large landslides mapped in the late Neogene deposits of this area. This study examined its patterns of movement using high temporal resolution, high-precision monitoring and explored the relationships between the movement and triggering mechanisms. During the 30 -year monitoring period, movement was always extremely slow, but included periods of faster and slower motion due to a combination of simultaneous basal sliding, internal plastic deformation and seasonal soil shrinkage and swelling. The data suggested that movement rate was not controlled by pore-water pressure or any other monitored parameter. Intervals of more rapid movement appear to follow toe erosion that debuttress the landslide mass, an example of which occurred following a flood in February 2004 that had a return period of about 100 years.
\end{abstract}

The high-temporal and spatial frequency of the monitoring and the measurement precision of the instruments have allowed new insights into the complex movement patterns of deepseated, slow moving rockslides. The patterns of movement observed here, and the techniques described to collect and analyse the data, are applicable to many slowly moving landslides in New Zealand, and to those occurring in similar environments worldwide.

\section{Keywords}

Geomorphology; Landslide monitoring; Hazard and risk mapping; Risk assessment; Landslides in urban areas

\section{Introduction}

In many very large (> $106 \mathrm{m3}$ ), slowly moving translational slides, the sliding mass moves along one or more planar or undulating basal shear surfaces (Cruden and Varnes, 1996 and Leroueil et al., 1996). Movement of a reactivated translational slide occurs along one or more fully developed slip surfaces (Leroueil et al., 1996) at residual strength (Skempton, 
1985). However, the recent availability of monitoring datasets with very high spatial and temporal resolutions, and improvements in instrument precision (e.g. Thiebes, 2012), highlight that movement of these landslides can be complex (e.g., Massey et al. 2013). Of course the type of movement is usually closely related to the triggering mechanism(s) (e.g.: Allison and Brunsden, 1990, Van Asch et al., 2009 and Carey, 2011), with changes in porewater pressure often being key (e.g., Picarelli, 2007). However, several studies find that the relationship between pore-water pressure and movement rate can be surprisingly complex (e.g.: Corominas et al., 2005, Matsuura et al., 2008 and Ng and Petley, 2009). Whilst this relationship is often poorly constrained, a recent study indicates that displacement in such landslides is not linked only with sliding along a basal slip surface (Massey et al., 2013), but also with internal deformation of the landslide mass: linkages that can be resolved with very high resolution monitoring (Massey, 2010 and Thiebes, 2012). This suggests that further research is needed into these more complex landslide mechanisms.

Thus, the aim of the study reported here was to investigate patterns of reactivated landslide movement using high-temporal resolution and high-precision monitoring to explore the relationships between movement patterns and triggering mechanisms, based on the analysis of $>30$ years of surface and subsurface movement patterns - including five years of high-resolution monitoring - of the Taihape landslide, which is located in central North Island, New Zealand (Fig. 1). This landslide is a large, reactivated, deep-seated, translational landslide (on the Cruden and Varnes, 1996, scheme) that displays slow but variable rates of movement, and deformation which damages homes and supporting infrastructure. 


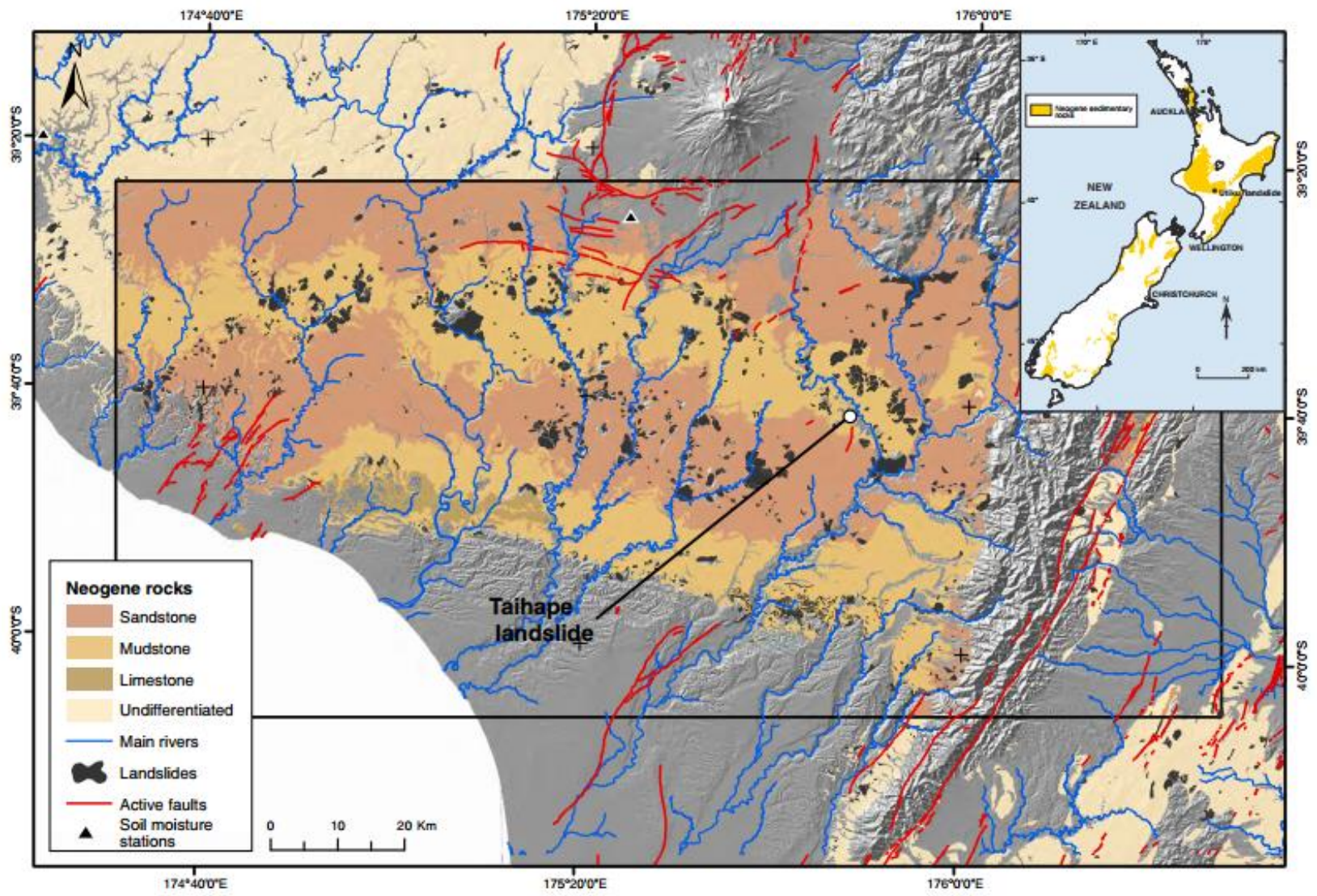

Fig. 1.

The inset map shows the distribution of Neogene-age sedimentary rocks in New Zealand. The larger map shows the distribution of landsides with surface areas greater than $2000 \mathrm{~m} 2$ in Neogene-age sedimentary rocks of lower North Island New Zealand. The mapped landslide polygons are taken from the GNS Science large landslide database. The main geological units and active faults are taken from QMap Series, Sheets 7 and 8 (Townsend et al., 2008; and Lee et al., 2012). Note the grey area is the background shade model for New Zealand, based on the $20 \mathrm{~m}$ LINZ digital elevation model.

\section{Geological and geomorphology of the Taihape landslide}

\subsection{Regional setting}

The Taihape landslide is located in the lower central part of New Zealand's North Island (Fig. 1), within the widely distributed weekly consolidated Neogene-age marine deposits. It is one of over 7000 landslides with plan areas $>2000 \mathrm{~m} 2$ in these materials (Fig. 1), which have been mapped by GNS Science and are contained in their National Landslide database (described by Dellow et al., 2005). The majority of these landslides are relatively deepseated, translational slides that move slowly when they are active (Massey, 2010 and Massey et al., 2013). These landslides have developed due to a combination of regional geological and geomorphological controls, including: 


\section{i. Geological materials -}

a) The dominant geological materials in the area belong to the Taihape Mudstone Formation, which comprise a series of interbedded fine-grained sandstone, sandy mudstone and sandy siltstone units (Lee et al., 2012). The Taihape landslide has formed within one of the sandstone units within this formation. This sandstone can be classified as being extremely weak to weak, slightly greenish grey, silty sandstone; very fine grained, with some ovoid cobble- and boulder-sized calcareous concretions that are strong to extremely strong (in the engineering-geological classification of New Zealand Geotechnical Society, 2005). These sandstones are generally massive with very few discontinuities; where discontinuities are present, they tend to be within landslide-displaced blocks or within outcrops adjacent to mapped landslides, and therefore possibly related to retrogression and enlargement of the landslide. The sandstone units within the Taihape Mudstone formation have unconfined compressive strengths that range between $<1$ and $20 \mathrm{MPa}$ (Read and Miller, 1990).

b) Hautapu Valley Agglomerate and other Upper Quaternary debris flow/lahar deposits from Mount Ruapehu, an active volcano about $100 \mathrm{~km}$ north of Taihape (Cotton, 1944, Te Punga, 1952 and Thompson, 1982), mantle many of the slopes in the area. The agglomerate comprises andesite clasts in a loose to medium dense, sandy silt matrix;

c) Within the Taihape mudstone formation there are several regionally persistent clay layers referred to as "clay seams", located at different stratigraphic heights within the formation (e.g.: Stout, 1977, Thompson, 1982, Mountjoy and Pettinga, 2006, Reyes, 2007 and Massey et al., 2013). These clay layers are typically less than $100 \mathrm{~mm}$ thick and generally low in shear strength, with ring-shear test results on samples of the clay indicating a cohesion (c) of 0 to 10 and a friction angle $(\varphi)$ of $8.3( \pm 1)^{\circ}$ (uncertainties at $1 \sigma$ ) (Massey, 2010 and Kilsby, 2007). These test results are from samples of the clay retrieved from boreholes located on several landslides that are nearby, and are similar to the Taihape landslide (Table 1). They are predominantly smectitic layers, thought to represent diagenetically-altered air-fall tephra (tuff) ejected during large eruptions from the North Island volcanic systems (Thompson, 1982 and Reyes, 2007);

Table 1. Laboratory material parameters for the Taihape landslide materials.

\begin{tabular}{|c|c|c|c|c|c|c|}
\hline Material & Description $^{1}$ & $\begin{array}{l}\text { Unit weight } \\
\mathrm{kN} / \mathrm{m}^{3}\end{array}$ & Strength parameters & $\begin{array}{l}\text { Young's modulus } \\
\text { (MPa) }\end{array}$ & $\begin{array}{l}\text { Poisson's } \\
\text { ratio }\end{array}$ & Test method \\
\hline $\begin{array}{l}\text { Landslide debris - intact displaced } \\
\text { blocks }\end{array}$ & $\begin{array}{l}\text { Very fine grained sandstone, } \\
\text { extremely weak }\end{array}$ & 21 & $\begin{array}{l}c^{\prime}=35 \pm(5) \mathrm{kPa} \\
\phi^{\prime}=37^{*} \pm(8)\end{array}$ & $800 \pm(100)$ & 0.3 & $\begin{array}{l}\text { Triaxial tests } \\
\text { (Geotechnics Ltd.) }\end{array}$ \\
\hline Landslide debris - remoulded & Silty, fine sund, medium dense & 20 & $\begin{array}{l}c^{\prime}=0 \mathrm{kPa} \\
\phi^{\prime}=28^{*} \pm(5)\end{array}$ & 75 & 0.3 & $\begin{array}{l}\text { Ring shear tests Massey } \\
\text { (2010) }\end{array}$ \\
\hline Landslide slide surface Utiku & Silty clay, very soft & 19 & $\begin{array}{l}c^{\prime}=4 \pm(6) \mathrm{kPa} \\
\phi^{\prime} r=8.3^{*} \pm(1)\end{array}$ & 10 & - & $\begin{array}{l}\text { Ring- and direct-shear tests } \\
\text { Massey (2010) }\end{array}$ \\
\hline Landslide slide surface confluence & Silty clay, very soft & 20 & $\begin{array}{l}c^{\prime}=0 \pm(3) \mathrm{kPa} \\
\phi^{\prime} r=8.2^{*} \pm(1)\end{array}$ & - & - & $\begin{array}{l}\text { Ring-shear tests } \\
\text { Kilsby (2007) }\end{array}$ \\
\hline Bedrock -Taihape mudstone & Sandy siltstone, very weak & 21 & $\begin{array}{l}c^{\prime}=300 \pm(50) \mathrm{kPa} \\
\phi^{\prime}=50^{\circ} \pm(10)\end{array}$ & $1000 \pm(500)$ & 0.35 & $\begin{array}{l}\text { Triaxial tests Read and Miller } \\
\text { (1990) }\end{array}$ \\
\hline
\end{tabular}

${ }^{1}$ Material description as per New Zealand Ceotechnical Society (2005).

ii. Geological Structure - The long-term regional tectonic setting of the Taihape area is one of gentle post-Miocene folding and east-west compression (Lee et al., 2012). The regional 
dip of bedding (including that of the clay seams) is $3-7^{\circ}$ towards the SSE, but bedding becomes locally steeper near geological faults (Lee et al., 2012);

iii. River incision - Regional Late-Neogene uplift rates are estimated to be $~ 1.5-2.0$ $\mathrm{mm} /$ year (Pillans, 1986 and Pulford and Stern, 2004), which has led to the development of deeply incised river gorges and has debuttressed the toes of several slopes, inducing instability;

iv. Seismicity and precipitation - The area is seismically active and experiences a high frequency of both intense and long-duration precipitation events that may trigger new landslides and reactivate existing failures.

The climate of Taihape is temperate oceanic in the Köppen-Geiger classification, characterised by: warm summers (December through to February, average daytime temperature of $22^{\circ} \mathrm{C}$ ); and cooler winters (June to August, average daytime temperature of $11^{\circ} \mathrm{C}$ ). The mean monthly rainfall is $70 \mathrm{~mm}$ in winter and $81 \mathrm{~mm}$ in summer; and the mean total annual rainfall is $960 \mathrm{~mm}$, from data collected between 1912 and 2015 at the Rangitikei District Council's gauge located at the Taihape Town Hall. These data suggest rainfall is not strongly seasonal.

\subsection{Landslide description}

The Taihape landslide (Fig. 2), is one of the very few large landslides in New Zealand's Neogene-age marine deposits which have undergone detailed engineering geological investigation and monitoring. It is centred at $30.680^{\circ} \mathrm{S}, 175.791^{\circ} \mathrm{E}$ with an elevation range between $550 \mathrm{~m}$ above mean sea level (AMSL) at the crown and $450 \mathrm{~m}$ AMSL at the toe. The approximate volume of the landslide is $1.8 \times 107 \mathrm{~m} 3$ and its surface area is about 67 ha (Thompson, 1982) (Fig. 3). There are about 200 households on the landslide, along with the former site of St Joseph's Primary School, which was relocated in April 2007 because of landslide-induced damage during a period of more rapid landslide movement. 


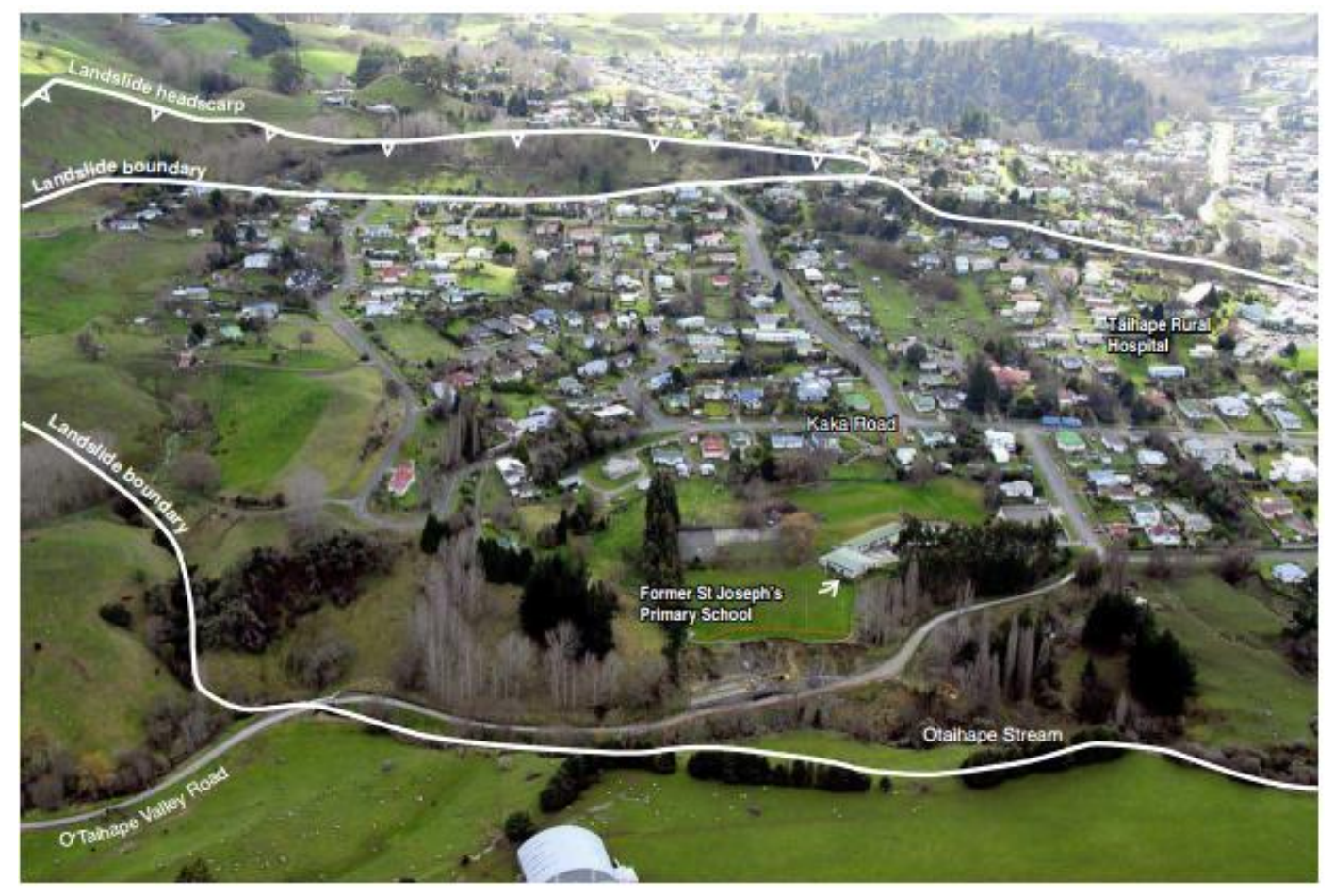

Fig. 2. Aerial oblique view of the Taihape landslide taken in 2007.

Source: G. Hancox, GNS Science. The annotations show the inferred landslide head scarp and boundary as well as some of the main features on the landslide. 


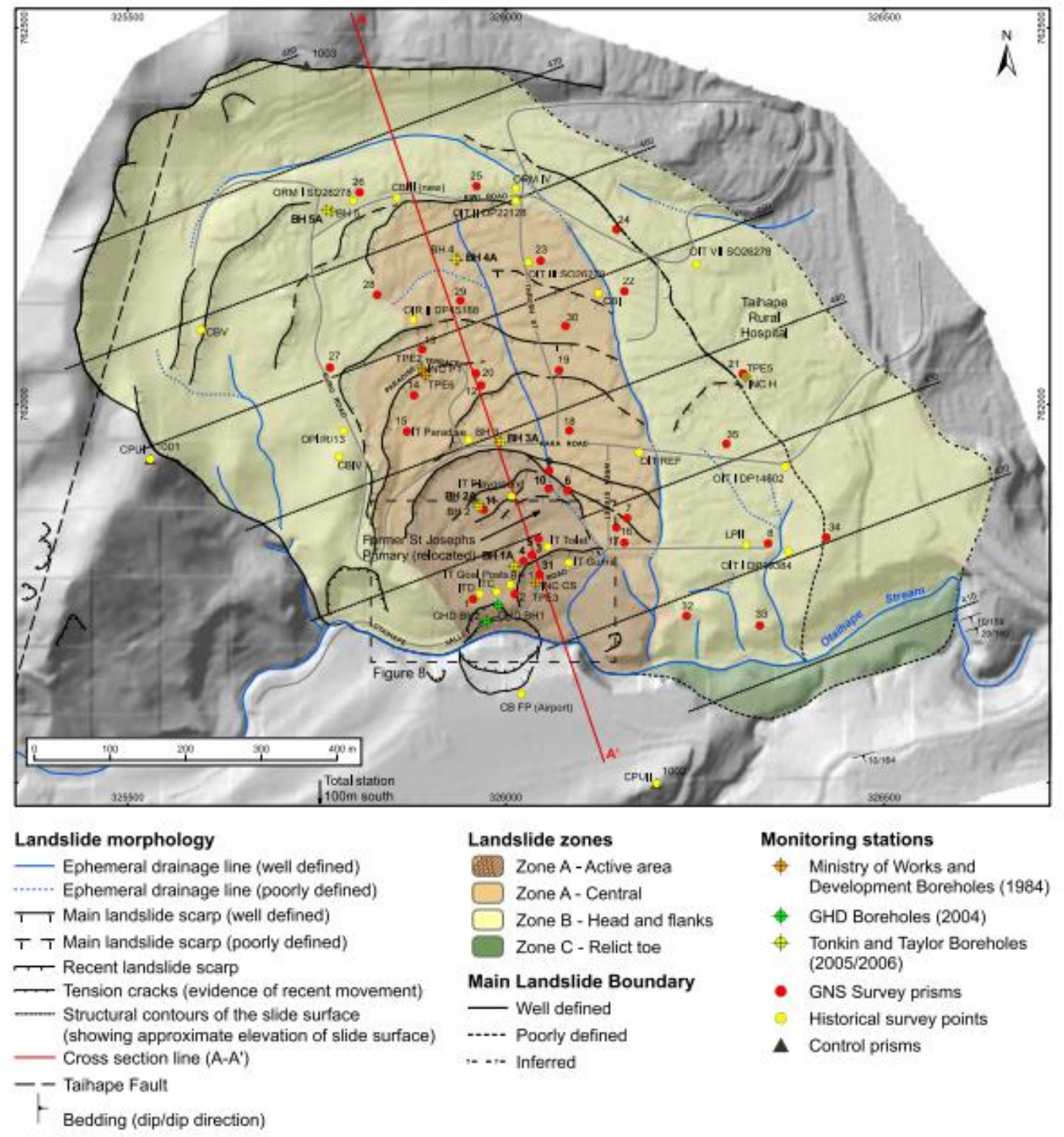

Fig. 3. The engineering geology of the Taihape landslide. The shade model is based on a $2 \mathrm{~m}$ digital elevation model generated from 2004 aerial photogrammetry. Coordinates and bearings in terms of Geodetic Datum 2000.

The Taihape landslide is at its maximum about $1300 \mathrm{~m}$ long and $900 \mathrm{~m}$ wide (Fig. 3), with a prominent head scarp. Most of its slide blocks are bounded by drainage lines that have been modified by urban development. Distinct breaks in slope form scarps between slide-block horsts and depressions within the slide mass, which form extensional grabens in which water ponds seasonally. The landslide is bounded at the toe by the Otaihape Stream and at its head by two linear scarp slopes (slope angles $30^{\circ}$ to $35^{\circ}$ and dip directions of $100^{\circ}$ and $170^{\circ}$ respectively). The western scarp slope with a dip direction of $100^{\circ}$ has a strike that is consistent with that of a mapped fault (Fig. 3), which has been classified as being active (Litchfield et al., 2007). The eastern boundary of the landslide is not as well defined as that to the west, and may have been modified by human activity and other landslides unrelated to the main slide. 
The landslide can be broadly divided into two based on slope morphology and monitored surface-movement rates:

A. A central area that has been active in the last 40 years, which extends to the toe and forms a general depression; and

B. A surrounding area with relatively low activity.

The two areas can be further subdivided on the basis of geomorphological features that reflect differential surface displacement between slide blocks and differences in material properties of the debris.

The main geological materials found in and around the landslide are (youngest to oldest):

1) Landslide debris: the majority of the Taihape landslide mass is derived from a sandstone unit within the Taihape mudstone formation. The debris has been subdivided into three sub-units that represent increasing amounts of remoulding generated by landslide movement. These comprise:

a) Intact displaced blocks of sandstone;

b) Partially remoulded rafts of intact sandstone, grading to;

c) Remoulded sandstone at the landslide toe.

2) Basal slide surface: the basal slide "surface"comprises a thin clay layer that varies in thickness from 0.03 to $0.3 \mathrm{~m}$, and was inferred from boreholes drilled through the landslide. Many similar thin (1-20 mm) clay layers are recognised in the Taihape mudstone formation (Thompson, 1982). These clay layers are concordant with bedding and bedding orientations, and laboratory-test results suggest they are at residual strength (Table 1). Table 2 contains a description of the inferred slide-surface materials, based on the logging of cores retrieved from boreholes through the landslide.

Table 2. Landslide slide-surface details derived from boreholes.

\begin{tabular}{|c|c|c|c|c|}
\hline Drill hole & $\begin{array}{l}\text { Depth below } \\
\text { ground level } \\
\text { ( } \mathrm{mbgl}^{1} \text { ) }\end{array}$ & 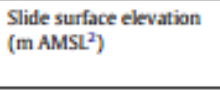 & $\begin{array}{l}\text { Slide-zone surface } \\
\text { thickness (m) }\end{array}$ & Description ${ }^{3}$ \\
\hline TPE3 & 16.50 & 427.9 & 0.03 & $\begin{array}{l}1-\mathrm{cm} \text { thick soft fracture zone inclined at } 45^{\circ} \text {; hard, brittle fractures. Contains fragments up to } 2 \mathrm{~cm} \\
\text { of blue grey sandstone. }\end{array}$ \\
\hline GHD BH1 & 24.30 to 24.60 & 39620 & 0.30 & Wet, loose, silty sand with gravel base (thin shear zone). \\
\hline BH1 & 22.85 & 427.9 & 0.15 & $\begin{array}{l}\text { Highly fractured zone of sheared material (crush zone) with some clay gouge directly overlying } \\
\text { assumed bedrock. }\end{array}$ \\
\hline BH2 & 24.50 & 433.6 & 0.10 & $\begin{array}{l}\text { Highly disturbed sheared zone of silty sand/sandstone with a } 10 \mathrm{~mm} \text { thick layer of clay bands ( } 2 \text { to } \\
3 \mathrm{~mm} \text { thick), at } 24.5 \mathrm{~m} \text { bgl }\end{array}$ \\
\hline $\mathrm{BH} 3$ & 24.15 & 441.5 & 0.03 & $\begin{array}{l}\text { Sharp sheared contact between disturbed landslide debris and assumed bedrock. Shear surface } \\
\text { consists of a clay band ( } 2 \text { to } 3 \mathrm{~mm} \text { thick), within a crushed zone with polished slickenside surfaces. }\end{array}$ \\
\hline BH4 & 33.25 & 452.3 & 0.02 & $\begin{array}{l}\text { Sharp sheared contact between disturbed landslide debris and assumed bedrock Shear surface } \\
\text { consists of a clay gouge (up to } 20 \text { mm thick). }\end{array}$ \\
\hline BHS & 44.15 & 464.3 & 0.01 & $\begin{array}{l}\text { Sandy clay layer up to } 7 \mathrm{~mm} \text { thick, with dark brown staining below, dry, darker grey slightly wavy } \\
\text { base. (Not an obvious feature, slip surface could be deeper) }\end{array}$ \\
\hline
\end{tabular}


3) Hautapu Valley Agglomerate and other Upper Quaternary debris flow/lahar deposits mantle most of the landslide surface. Field mapping of exposures and logging of core from the boreholes drilled into the landslide suggest this material generally forms a deposit over most of the landslide, and is up to $9 \mathrm{~m}$ thick in the boreholes;

4) In-situ sandstone of the Taihape mudstone formation can be found in outcrop outside the boundary of the mapped landslide. In outcrop, this material is relatively massive in nature with a dip of $5-10^{\circ}$, towards a direction (dip direction) of $150-190^{\circ}$ (dip/dip direction) mapped in the area by the authors and others (e.g. Lee et al., 2012).

\subsection{Landslide slide surface}

A laterally persistent clay seam was identified in Boreholes 1, 1 A, 2, $2 \mathrm{~A}, 3,3 \mathrm{~A}, 4$ and $4 \mathrm{~A}$ (Fig. 4), which is interpreted to be the primary shear surface at the base of the landslide. This clay seam was not found in borehole 5 and $5 \mathrm{~A}$, suggesting that the slide surface may have been below that borehole's termination depth. The clay from the borehole cores was classified as silty clay, with angular fine gravel of fine-grained sandstone; dark grey, soft, with a shear (slickensided) fabric in parts (adopting the New Zealand Geotechnical Society (2005) scheme). Gravel-sized rock fragments (fine- to coarse-sized gravel, 2 to $60 \mathrm{~mm}$ in grain size) were found in the upper parts of the slide-surface material and are interpreted as being comminuted sandstone (Table 2). The slide-surface material was similar to that found in boreholes and in a trench at the Utiku landslide (Massey, 2010 and Massey et al., 2013), another large active landslide in this area. X-ray diffractometry (XRD), scanning electron microscopy with an energy dispersive X-ray attachment (SEM-EDX) and chemical analysis, indicate that the clay portion of the slide surface material tested comprised 30-35\% smectite matrix (Reyes, 2007). On a regional basis, the assumed slide surface corresponds to the uppermost and thickest of the clay layers (tuff deposits) in the Taihape mudstone formation, as mapped by Thompson (1982). 

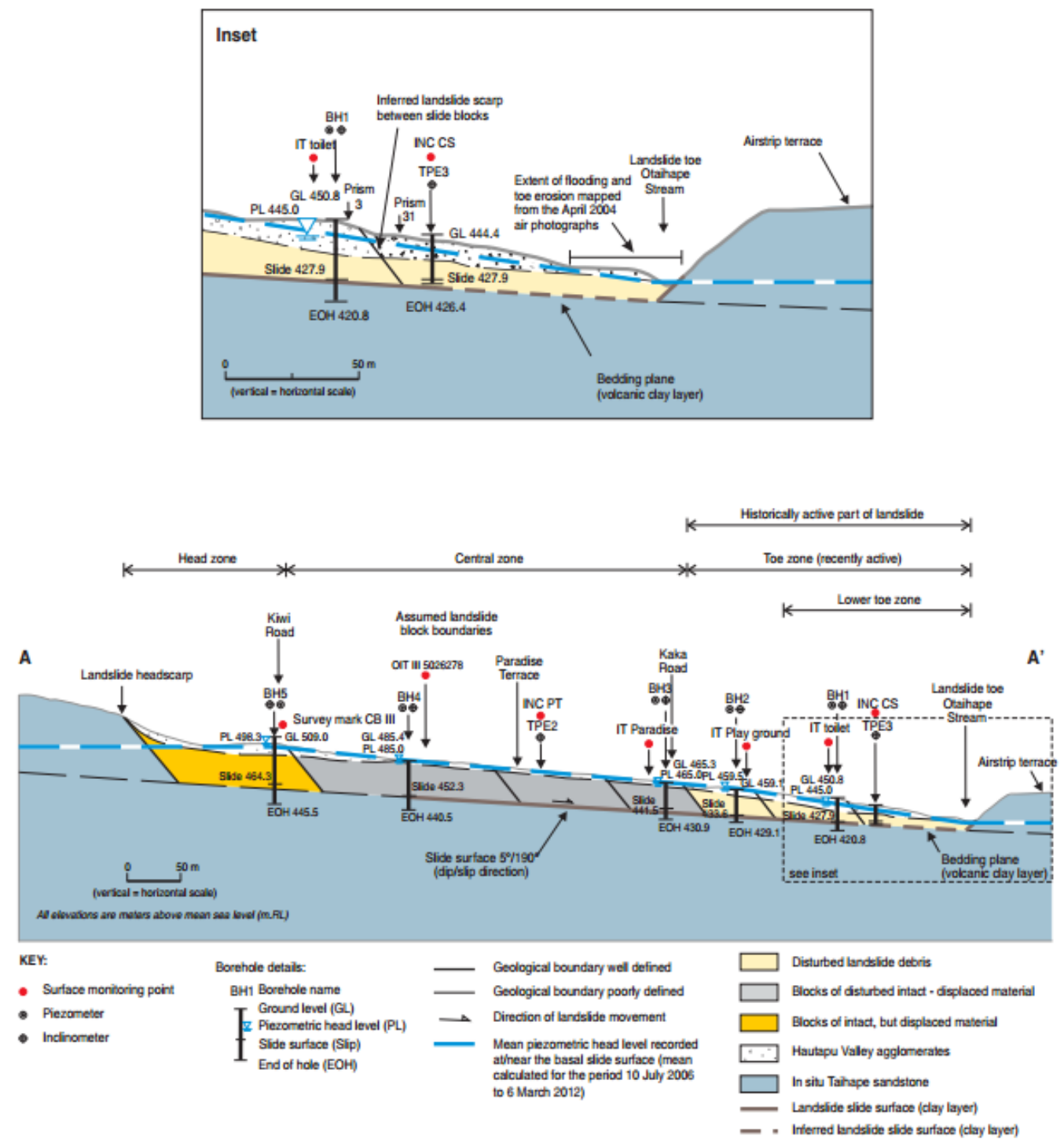

Fig. 4. Schematic long section $A-A^{\prime}$ through the Taihape landslide. The location is shown on Fig. 3. Inset: more detailed view of the landslide toe area adjacent to Otaihape Stream.

Least-squares analysis of three-point solutions from various combinations of the boreholes (using the depths of the identified slide surfaces) indicated that the slide surface is close to planar, with an average dip/dip direction of $4-5^{\circ} / 160-165^{\circ}$. The dip/dip direction of bedding mapped in the area by the authors and others (e.g. Lee et al., 2012) is 5-10\%150-190\%, similar to those of the clay forming the slide plane. Structural contours on the in-situ clay layer ( Fig. 3) correspond to the depth of the slide plane at the landslide base, indicating that the landslide is translational. At the toe, the slide surface is inferred to be about $6 \mathrm{~m}$ below the base level of Otaihape Stream, such that the landslide toe is confined (Fig. 4 inset). However, no subsurface ground investigations were carried out in this area to confirm this. The geomorphology of the toe of the landslide tends to be "hummocky" and appears "disturbed" and is relatively low angle, about $5-10^{\circ}$. The material retrieved from $\mathrm{BH} 1$ and BH1A (Fig. 3 ) in this area indicated that the displaced sandstone above the slide surface was remoulded and quite different to the material retrieved from $\mathrm{BH} 3,3 \mathrm{~A}, 4$ and $4 \mathrm{~A}$, which was more intact. In contrast, the southern bank of Otaihape Stream is formed of continuous, 
near vertical outcrops of in situ sandstone, with no evidence of landslide movement apparent in the field. The stream is at the boundary between the in situ sandstone and the "hummcocky" landslide debris.

\section{Methods}

This analysis uses data collected from field mapping; ground investigations comprising twelve boreholes; laboratory testing of the main materials forming the landslides; and in situ monitoring. The monitoring network installed on the landslide recorded: i) surface and subsurface movement; ii) pore-water pressure; iii) rainfall; and iv) river stage. Earthquakeinduced ground accelerations were also recorded on the landslide, the largest being 0.34 $\mathrm{m} / \mathrm{s} 2$ ( $0.034 \mathrm{~g}$ or $\mathrm{MM}<$ II on the Modified Mercalli scale), which triggered no measurable landslide movement, and are therefore not discussed further. Although systematic monitoring prior to 1984 was not undertaken, records show the landslide was active in 1971 (Massey, 2010).

\subsection{Installed monitoring networks}

Surface movement at Taihape began in 1984 using a network of pegs, initially surveyed using a theodolite, but latterly in 2004 by GPS equipment, at a variable frequency (for locations, see Fig. 3). Subsurface movement of the landslide was measured from 2005 to 2010 using inclinometer surveys (Massey, 2010).

A monitoring system capable of high temporal and spatial resolution measurement of landslide movement was installed in June 2006, along with equipment capable of measuring other key variables. Surface movement was monitored using an automated robotic totalsurvey station installed on a stable hilltop south of the landslide toe (Fig. 3) that measured the angle and distance to survey reflector prisms at hourly intervals. The manufacturer's certified precision of the total-survey station is: $0.0042^{\circ}$ of arc (horizontal and vertical angle measurement); and line-of-site distance, $\pm 1 \mathrm{~mm}$; the range is specified as $2500 \mathrm{~m}$. Thirty five survey prisms were installed on the landslide, and their movements were referenced to three prisms on stable ground beyond the western and eastern flanks of the landslide and above the landslide head scarp. The prism locations on the landslide (Fig. 3) were based on geomorphological mapping of landslide features, and patterns of historical ground deformation. The prism sites were selected to measure relative displacements across significant geomorphological features such as tension cracks and scarps. 30 prisms were mounted about $1 \mathrm{~m}$ above ground level on rigid poles installed about $1.5 \mathrm{~m}$ into a $200 \mathrm{~mm}$ diameter augured hole backfilled with concrete. Five prisms were mounted on buildings. The surface-movement monitoring equipment was reliable, with data being collected on average for $93.7 \%$ of the study period for each prism. The root mean square error on the daily position of the prisms was $\pm 5.6 \mathrm{~mm}$ normal (perpendicular) to line of sight, $\pm 1.1 \mathrm{~mm}$ 
distance (from total station to prism) and $\pm 7 \mathrm{~mm}$ vertically. Full details of the monitoring system are provided in Massey (2010).

Inclinometer tubes were installed in five boreholes (BH1 to BH5) in July 2005 and June 2006, which were anchored below the slide surface. Displacements of the $70 \mathrm{~mm}$ diameter plastic casings were monitored using test method ASTM D6230:05 and probe-type Inclinometers with readings at $0.5 \mathrm{~m}$ intervals. Tubes were measured at approximately monthly intervals, or after significant surface movement of the landslide had been detected in the total-station data. Inclinometer accuracy is quoted as $\pm 6 \mathrm{~mm}$ over $25 \mathrm{~m}$ of tubing (Slope Indicator, 2005) and the $1 \sigma$ measurement precision between any two surveys was about $\pm 2 \mathrm{~mm}$.

Pore-water pressures within the landslide were measured using Casagrande piezometer standpipes in boreholes $\mathrm{BH} 1 \mathrm{~A}-\mathrm{BH} 3 \mathrm{~A}$ and $\mathrm{BH} 5 \mathrm{~A}$, adjacent to inclinometer holes. Each piezometer measured within a screened and bentonite-sealed response zone, with two of the tubes measuring two response zones per hole. The depth and length of each response zone was selected after examination of the borehole logs. The lower response zones corresponded to the logged landslide slide surface, into which vibrating-wire pressure transducers were installed. The other response zones correspond to changes in material within the slide mass and the water levels in these standpipes were monitored with a manual dip meter.

All pore-pressure measurements used in these analyses were recorded the tip of the vibrating-wire sensor. Hourly readings (in Hertz) from vibrating-wire piezometers BH1A $\mathrm{BH} 5 \mathrm{~A}$ were converted to pressure and averaged over each $24-\mathrm{h}$ period (UTC), to obtain a daily averaged pore-water pressure for each instrument. Readings were corrected for barometric effects using data from a barometric pressure sensor on the landslide. The stated accuracy of the vibrating-wire piezometers is $\pm 0.1 \%$ of the operating pressure (Geokon, 2005), which for the Taihape piezometers was $700 \mathrm{kPa}$, giving an expected precision error of $\pm 0.7 \mathrm{kPa}$ (about $\pm 0.07 \mathrm{~m}$ of piezometric head). Instrument reliability was about $99 \%$, based on the mean number of daily readings as a proportion of the total number of days the instruments were installed.

Rainfall was recorded using two tipping-bucket rain gauges ( $0.2 \mathrm{~mm}$ per tip) located adjacent to $\mathrm{BH} 2$ and $\mathrm{BH} 5$ (Fig. 3). The $0.2 \mathrm{~mm}$ increments recorded over each 24 -h period (midnight to midnight UTC) were summed to determine daily rainfall at each station.

\subsection{Numerical modelling}

Quantitative stability modelling was used to validate the residual shear-strengths of the clay slide surface of the landslide derived both from laboratory testing of slide-surface material and from other relevant published data. Back-analysis of landslide displacements using the monitored piezometric head levels during the main period of movement was undertaken using the limit equilibrium Rocscience software SLIDE ${ }^{\mathrm{TM}}$ and the finite-element software PHASE2 (RS2) ${ }^{\mathrm{TM}}$, based on an idealised section (Fig. 4). The section line is parallel to the main direction of landslide movement derived from the surface monitoring results (1984 to 
2015). For the limit equilibrium models the factor of safety was calculated using the general method of Morgenstern and Price (1965). The failure surfaces were defined manually using the results from the field mapping, ground investigations and the inclinometer surveys. The finite-element modelling used the shear-strength reduction technique for determining the shear stress reduction factor, which is equivalent to the slope factor of safety, (e.g., Dawson et al., 1999) as derived from the limit equilibrium software. Finite-element meshes for the models were generated using uniform, 3-noded triangles with between 2000 and 3000 elements and about 1500 nodes per model. For all models, the Mohr-Coulomb strength parameters were adopted and groundwater was represented using piezometric lines.

\section{Monitoring results}

Between the 1971, when movement was first noticed, and 2015 (when the last survey was carried out), field observations and monitoring results suggest that landslide movement was always within the extremely slow to very slow (0.016-1.6 ma-1) range of the landslidemovement classification of Cruden and Varnes (1996).

\subsection{Surface movement - prior to 1985}

The Taihape landslide is thought to have initiated sometime between 11,000 and 1800 years ago (Thompson, 1982). Movement of the landslide was first recorded in 1971 (Gillespie, 1971). The upslope limit of movement in 1971 was mapped by Gillespie (1971) and corresponds to the same active area of the landslide (Zone A, Fig. 3) as inferred from the more recent survey results (1985 to present).

\subsection{Surface movement -1985 to July 2015}

A total of 13 surveys of the manual surface movement network were made since 1985, including a survey in July 2015 to examine movement since the main monitoring period ended in 2011. The data show that the most active part of the landslide is the toe area, south of Kaka Road (Zone A, Fig. 3). Most of the survey pegs outside of this area showed no movement exceeding survey error $( \pm 0.02 \mathrm{~m}$, at $68 \%$ confidence, all errors in this study are given as $1 \sigma$ unless otherwise stated). Vertical movement was not available for the historical survey network. For the survey pegs on the active landslide (Zone A, Fig. 3), velocity vectors were consistently towards the down slope direction (south-southeast. Bearing $152^{\circ}-168^{\circ}$ ) (Fig. 6), in the dip direction $\left(160^{\circ}-165^{\circ}\right)$ of the slide surface.

Horizontal displacements of selected survey pegs were plotted along their main motion bearings (Fig. 7). Cumulative displacement for survey mark Inclinometer CS (the only consistently monitored long-term survey peg in the landslide toe, Zone A) showed that 
historical motions had mainly been regular, with a main period of more rapid (but still extremely slow) displacement between April 2004 and July 2006. The infrequent surveys poorly resolved the start and finish of this period of more rapid movement. The higher velocity movement event was also recorded by several other survey pegs on the landslide toe (Fig. 7 and Fig. 8). The largest horizontal displacement during this event was $0.17 \mathrm{~m}$ at survey mark Inclinometer CS. Movement decreased up slope from the toe: $0.12 \mathrm{~m}$ was recorded at mark IT Goal Posts; and $0.08 \mathrm{~m}$ at marks IT Toilet and IT Playground on the upper toe (in the former grounds of St Joseph's School). All of these survey pegs are located in the lower part of the landslide (Zone A) and correspond to the mapped area of movement in 1971 (Gillespie, 1971).

The higher-velocity movement between April 2004 and July 2006 followed a 100-year return-period storm (Horizons Regional Council, 2004) that occurred between 15 and 16 February 2004. Rainfall of $118 \mathrm{~mm}$ was recorded at Taihape on 16 February 2004, the largest daily rainfall recorded at that location since formal records began in 1912. About 180 $\mathrm{mm}$ of rain fell over a five-day period. This rainfall occurred during a period when annual rainfalls were substantially above the mean. However, other similar (though smaller) peaks in the rainfall record did not trigger faster movement of the landslide (Fig. 7). Results from the surveying of the historical monitoring network show that the period of faster movement started about two months after the storm, indicating a delayed landslide response if the storm were the trigger.

It is perhaps more important that the storm caused flooding and mapped erosion along Otaihape Stream at the toe of the landslide. Aerial photographs and field mapping after the storm (Massey, 2010) indicated that about $100 \mathrm{~m}$ of the southern edge of Otaihape Valley Road was undercut and fell into the stream and new landslide scarps and tension cracks were mapped along the edge of the road, as well as further up the slope (Fig. 8). The volume of material eroded in this area was not estimated at the time and it is not possible to survey in the toe area due to vegetation and topographic constraints. The authors have undertaken many periodic "walk-over" surveys of Otaihape Stream, comprising visual inspection of the stream banks, since June 2006 and most recently in June 2015. Although no significant erosion was identified during these inspections, it was noted in June 2015 that tension cracks and evidence of recent localised "slumping" of ground at the landslide toe into Otaihape Stream had occurred in the same location as occurred in 2004 (Fig. 8). The amounts of erosion noted during these inspections were minor compared to what occurred following the storm in February 2004.

\subsection{Surface movement - August 2006 to March 2011}

High-resolution displacement monitoring (1/08/2006-5/03/2011, about 4.6 years) commenced after the main period of faster movement. During the higher resolution monitoring, only those prisms on the toe of the landslide, south of Kaka Road (Zone A, Fig. 3), showed movement greater than survey error (Fig. 6 and Table 3). This area is consistent 
with the active area inferred from the historical survey results and from the field mapping in 1971. All other prisms located on the parts of the landslide outside Zone A did not record any movement greater than the associated survey error. It is therefore assumed that the landslide outside of Zone A has been stable during the monitoring period.

Table 3. Summary of prism and inclinometer displacements during the monitoring period that show horizontal displacements greater than the associated errors.

\begin{tabular}{|c|c|c|c|c|c|c|c|c|c|c|c|c|c|}
\hline \multirow{3}{*}{$\begin{array}{l}\text { Station } \\
\text { ID }\end{array}$} & \multirow{2}{*}{\multicolumn{3}{|c|}{ Monitoring period }} & \multicolumn{7}{|c|}{ Horizontal displacement } & \multicolumn{3}{|c|}{ Vertical displacement } \\
\hline & & & & \multirow{2}{*}{$\begin{array}{l}\text { Total } \\
\text { disp'. } \\
(\mathrm{mm}) \\
\end{array}$} & \multirow{2}{*}{$\begin{array}{l}\text { Mean } \\
\text { disp., } \\
(\mathrm{mm})\end{array}$} & \multirow{2}{*}{$\frac{1 \sigma}{(\mathrm{mm})}$} & \multirow{2}{*}{$\begin{array}{l}\text { Disp. } \\
\text { rate } \\
\mathrm{mm} / \mathrm{yr}\end{array}$} & \multirow{2}{*}{$\begin{array}{l}\text { Error on } \\
\text { rate } 1 \sigma \\
(\mathrm{mm} / \mathrm{yr})\end{array}$} & \multirow[t]{2}{*}{ Bearing } & \multirow{2}{*}{$\begin{array}{l}\text { Error on } \\
\text { bearing } 1 \sigma \\
(")\end{array}$} & \multirow{2}{*}{$\begin{array}{l}\begin{array}{l}\text { Mean } \\
\text { disp. }^{1}\end{array} \\
(\mathrm{~mm})\end{array}$} & \multirow{2}{*}{$\begin{array}{l}\text { Error on disp. } \\
1 \sigma \\
(\mathrm{mm})\end{array}$} & \multirow{2}{*}{$\begin{array}{l}\text { Translational disp. } \\
\text { angle } \\
\left(^{\circ}\right)\end{array}$} \\
\hline & Start & End & Days & & & & & & & & & & \\
\hline INC BH1 & 15/09/2005 & 20/07/2006 & 308 & 17 & 14 & 1 & 17 & 1.2 & 173 & 1 & $\mathrm{~N} / \mathrm{A}$ & N/A & N/A \\
\hline INC BH1 & 20/07/2006 & $2 / 10 / 2010$ & 1535 & 13 & 10 & 1 & 2 & 0.15 & 173 & 1 & N/A & N/A & N/A \\
\hline INC BH2 & $15 / 09 / 2005$ & 20/07/2006 & 308 & 25 & 22 & 2 & 27 & 1.2 & 142 & 1 & N/A & N/A & N/A \\
\hline P3 & 1/08/2006 & $5 / 03 / 2011$ & 1677 & 29 & 25 & 1 & 5 & 0.0 & 197 & 1 & -17 & 4 & -34 \\
\hline P4 & 20/07/2006 & $1 / 09 / 2009$ & 1139 & 17 & 15 & 3 & 5 & 0.1 & 169 & 2 & 0.3 & 3 & 1 \\
\hline P5 & $12 / 07 / 2006$ & $5 / 03 / 2011$ & 1697 & 25 & 26 & 2 & 6 & 0.0 & 159 & 1 & 2 & 4 & 5 \\
\hline P9 & $21 / 07 / 2006$ & 24/10/2010 & 1556 & 24 & 14 & 2 & 3 & 0.1 & 189 & 2.2 & 0 & 4 & -1 \\
\hline P10 & 20/07/2006 & 5/03/2011 & 1689 & 49 & 40 & 4 & 9 & 0.1 & 176 & 1 & -1 & 4 & -2 \\
\hline P11 & $22 / 07 / 2006$ & $5 / 03 / 2011$ & 1687 & 39 & 30 & 2 & 7 & 0.0 & 158 & 1 & 3 & 4 & 6 \\
\hline P6 & 23/07/2006 & $5 / 03 / 2011$ & 1686 & 7 & 14 & 3 & 30 & 0.0 & 310 & 9 & 1 & 4 & 5 \\
\hline P31 & $10 / 05 / 2007$ & $5 / 03 / 2011$ & 1395 & 6 & 8 & 4 & 22 & 0.1 & 329 & 4 & -9 & 4 & -47 \\
\hline P14 & $22 / 07 / 2006$ & $5 / 03 / 2011$ & 1687 & 0 & 1 & 1 & 0.1 & 0.1 & 189 & 31 & 3 & 5 & 78 \\
\hline
\end{tabular}

The prism data, along with the mapped geomorphic features and historical mapping, were used to delimit more clearly the active part of the landslide (Zone A, Fig. 3), which is about $11 \%$ of the area of the landslide as mapped. Vector bearings from the least-squares analysis of the horizontal time-series from the prisms in Zone $A$ were between $158^{\circ}$ and $197^{\circ}$ (i.e. towards the South), similar to the bearings from the historical survey movement (Fig. 6), and those from inclinometers in $\mathrm{BH} 1$ and $\mathrm{BH} 2$ (Table 3). The majority of the horizontal vector bearings shown by the prisms, historical survey marks and inclinometers were similar to the dip direction and structure contours of the bedding-parallel clay layer $\left(160^{\circ}-165^{\circ}\right)$, indicating that surface and subsurface movement were directly down-dip for this layer (Fig. 4).

\subsubsection{Surface movement of the active lower landslide (Zone A)}

To assist in identifying patterns of movement, the cumulative movement of prisms showing downslope movement greater than the associated errors were plotted along their main vector bearings (from the least-squares analysis) (Fig. 9A for the upper area of the active landslide; Fig. 9B for the lower area of the active landslide), along with displacements at depth for the nearest inclinometers in boreholes $\mathrm{BH} 1$ and $\mathrm{BH} 2$. Linear trend-lines fitted to the cumulative horizontal time-series from the prisms on the active landslide area show that the largest surface movements were recorded at prism Nos. 10 (9 $\pm 0.1 \mathrm{~mm} /$ year) and 11 (7 $\pm 0.1 \mathrm{~mm} /$ year). These prisms were near the head of the active part of the landslide, 
downslope from a prominent scarp (Fig. 3) that is inferred to mark the boundary between the lower active, and upper inactive parts of the landslide. The cumulative vertical time series from these prisms, showed no statistically significant trend over the monitoring period. The amount of horizontal prism movement decreased towards the toe below the former St Joseph's Primary School, as shown by prisms 3, 4 and 5, which all recorded mean horizontal movements of 5-6 $( \pm 0.1) \mathrm{mm} /$ year. Trend lines fitted to the vertical cumulative movement time-series from Prisms 4 and 5, located slightly further up slope from prism 3 and also on buildings with concrete foundation slabs, show no net vertical motion exceeding associated errors. Prism 3, however, located on a ground-anchored pole about $20 \mathrm{~m}$ upslope of the lower prominent internal landslide scarp, showed significant vertical (downward) movement of $-4( \pm 0.1) \mathrm{mm} /$ year. Prism 31 also recorded significant vertical (downward) movement of about $-2( \pm 0.1) \mathrm{mm} /$ year over the monitoring period. Prism 31 was located in a graben about $30 \mathrm{~m}$ downslope of prism 3 and about $10 \mathrm{~m}$ downslope of the prominent scarp. Movement vectors of these prisms indicate a translational angle - i.e. the angle of movement from the horizontal - of about $34^{\circ}$ for prism 3 and $47^{\circ}$ for prism 31 . Prism 31, however, shows a vector bearing that is upslope (i.e. towards the North), and represents a rotational movement, confirmed by "back-tilted" trees in the area around prism 31. Prism 6, on the flank of the scarp marking the boundary between active and inactive parts of the landslide (Fig. 6), also shows a similar vector bearing, i.e. upslope towards the north. As with prism 31, this movement is thought to relate to the position of the prism on the landslide. These results suggest that the prisms near or on landslide scarps and grabens show significant vertical displacement and sometimes rotation, whilst those prisms within slide blocks show predominantly horizontal motion.

The least-squares analysis was used to detect a significant linear movement trend, however, the motions of the prisms also showed statistically significant non-linear patterns occurring over shorter durations. To explore these, each horizontal time series was detrended by removing the linear extremely slow movement component. The residuals showed statistically significant cyclic movement (Fig. 10). Prisms 3-5 and 9-11 showed a repeating pattern of up- and down-slope horizontal motions amounting to about 10-20 mm/year (5$10 \mathrm{~mm}$ per half year in alternating directions) through the summer and winter, suggesting a seasonal origin. Downslope motion is represented by increasing cumulative movement and upslope motion by decreasing cumulative movement (Fig. 10). Most prisms showed downslope motion during winter and upslope motion in summer. However, the vector bearings of the detrended prism movements vary between the prisms. Some show downslope movement in summer, whilst others show up-slope or cross-slope movement over the same monitoring period. These trends suggest that local effects at the prism sites may control the seasonal slow surface movements. The de-trended time series from prisms 3-5 followed similar trends in the timing and amplitude of the peaks (peak to peak), whilst the peaks from prisms 9-11 although occurring at similar times, show varying amplitudes. Seasonal cycles were also identified in the vertical time series for prisms 3-5 and 9-11 (Fig. $9 C$ and D), where annual cycles represented movements of about $10 \mathrm{~mm} /$ year $(5 \mathrm{~mm}$ per half year in alternating directions) with upward movement in winter. The peak-to-peak vertical pattern generally appears to correlate with the peak-to-peak horizontal pattern. No 
evidence of seasonal cycles has been detected in inclinometer measurements of displacement at the slide surface. The seasonal displacements must affect the landslide to at least the depth of the bases of the prism monuments that are at depths of between 1.5 and $2 \mathrm{~m}$ below the surface.

\subsection{Subsurface movement}

Inclinometer monitoring through the slide base was undertaken between 15 September 2005 and 2 October 2010. Over the monitoring period, only inclinometers in BH1 and BH2 (in the toe of the landslide) showed significant shear displacement at depth (Fig. 5). Whilst the inclinometer in $\mathrm{BH} 3$ showed minor displacement at depth, no other inclinometer showed movement consistent with landslide displacement. Deformation measurements in $\mathrm{BH} 1$ and $\mathrm{BH} 2$ suggest the presence of only one slide surface, at a depth correlating with the clay seam identified in borehole logs. These inclinometers indicated deformation within a zone narrower than the 0.5 m measurement increment. Inclinometers $\mathrm{BH} 3$ and $\mathrm{BH} 4$ showed sinusoidal deformation between $11 \mathrm{~m}$ and $13 \mathrm{~m}$ below ground level, which represents buckling of the inclinometer casing into voids between the casing and the walls of the hole, rather than landslide movement. Borehole logs for these depths indicated core loss, which may relate to voiding or a particularly low-strength layer. Inclinometer monitoring included the end of the period of faster displacement that began after April 2004 and ended around the survey on 20 July 2006 (Fig. 9A and B). Between 15 September 2005 and 20 July 2006, the mean cumulative horizontal displacements at the slide surface in $\mathrm{BH} 1$ and $\mathrm{BH} 2$ were 14 $( \pm 1)$ and $22( \pm 2) \mathrm{mm}$, at rates of 17 and $27( \pm 2) \mathrm{mm} /$ year towards bearings of $173^{\circ}$ to $142^{\circ}$ $\left( \pm 1^{\circ}\right.$ ) respectively (Table 3 ). Between 20 July 2006, and 2 October 2010, the mean slidesurface displacement in inclinometer tube BH1 was $10( \pm 1) \mathrm{mm}$ at a rate of $2( \pm 0.2)$ $\mathrm{mm} /$ year towards bearing $173( \pm 1)^{\circ}$. The data suggest that the faster movement recorded at the slide surface coincided with the faster surface movement recorded at the surface by the historical survey network. During this period of faster displacement, the amount of monitored movement in Inclinometer $\mathrm{BH} 2$ (in the upper part of the active landslide) was larger than that recorded in Inclinometer BH1 (in the lower part), in common with the surface measurements. All inclinometer displacements were consistent with the depth and dip direction $\left(160^{\circ}-165^{\circ}\right)$ of the identified clay layer. The inclinometer tube in $\mathrm{BH} 2$ (Fig. 5) sheared off sometime after the 5 October 2006 survey. Monitoring of the other inclinometers continued until October 2010. There was no trace of cyclic motion in the inclinometer records. 
BH5

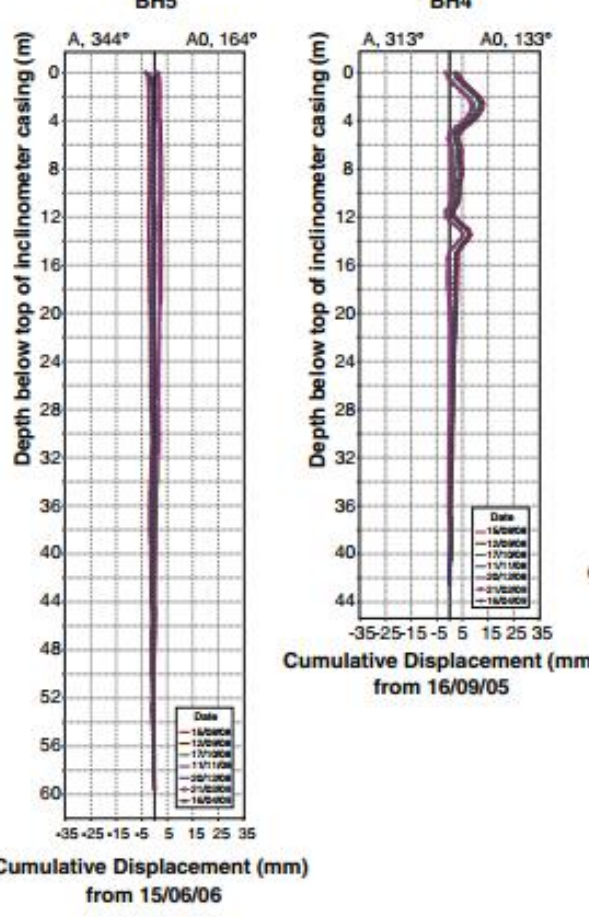

Вн3

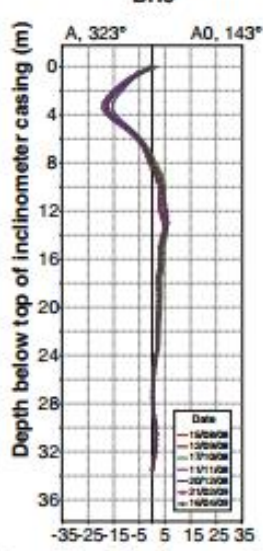

umulative Displacement (mm)

from 16/09/05
BH2

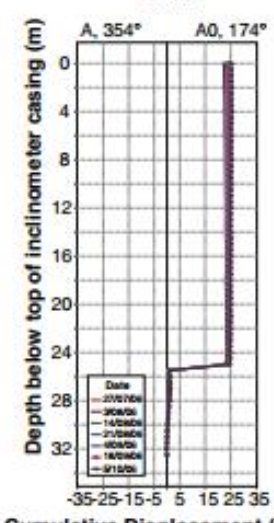
Cumulative Displacement (mm)
from 15/09/05

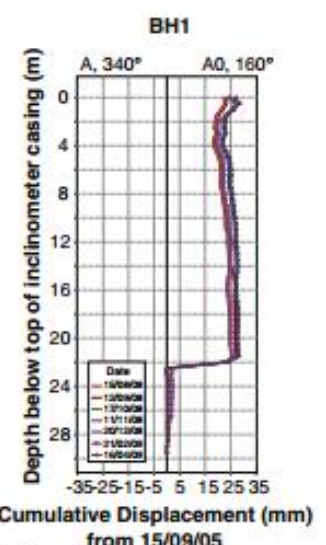

from 15/09/05

Fig. 5. Plots of cumulative displacement for inclinometers $\mathrm{BH} 1$ to $\mathrm{BH} 5$ in the direction of the (A0) axes, corrected to grid north. The inclinometers are ordered left to right as they occur along the cross section $A-A^{\prime}$ (Fig. 4). Down-hole measurements were made at $0.5 \mathrm{~m}$ increments. The readings have been plotted versus depth $(\mathrm{m})$ measured from the top of the inclinometer casing. The cumulative displacements are referenced from the bottom of the tube. The plotted point at any depth is the sum of incremental lateral deviations up to and including that depth. 


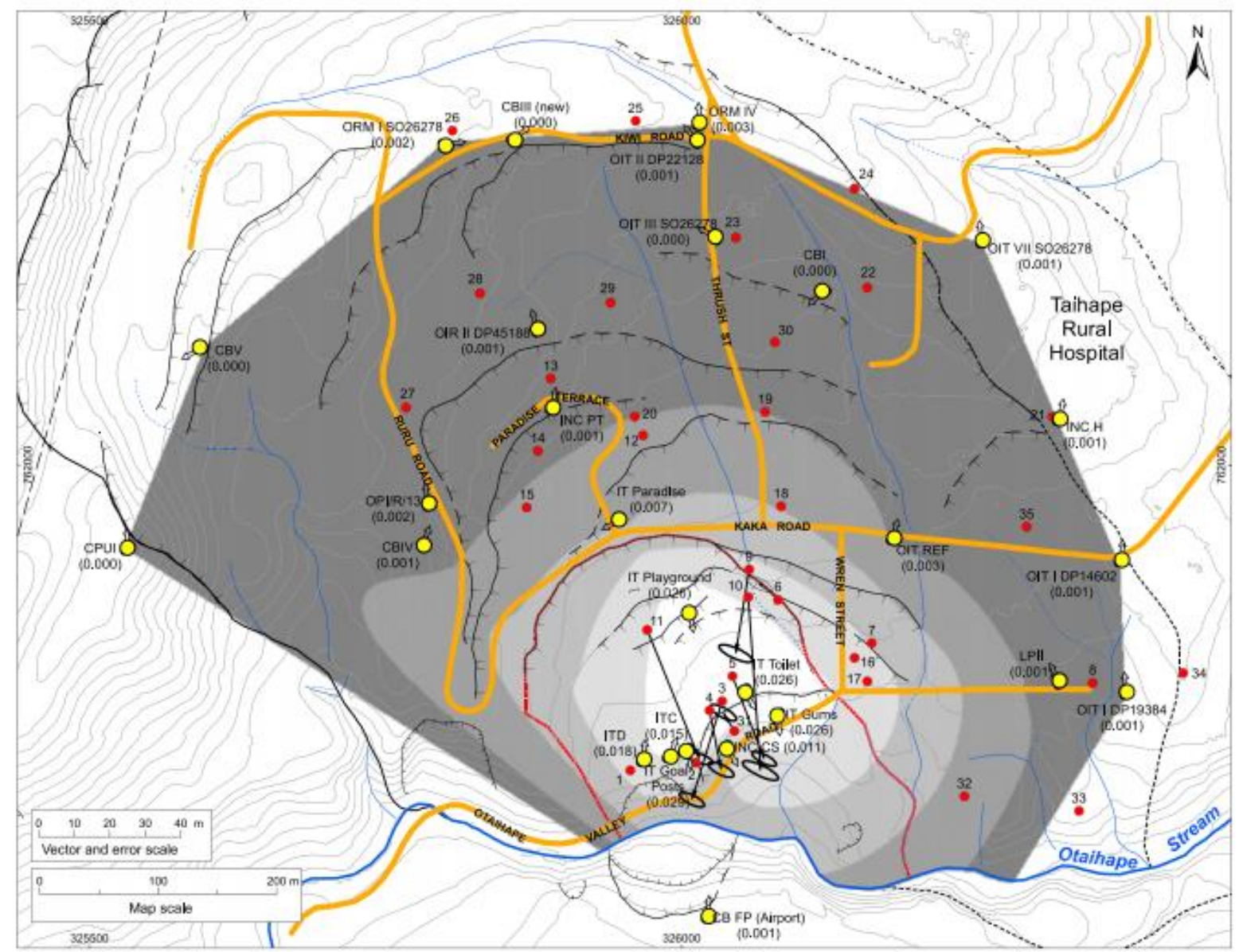

\section{Average rate of surface displacement ( $\mathrm{mm} /$ year)}

\begin{tabular}{|l}
\hline$<5$ \\
$5-10$ \\
$10-15$ \\
$15-20$ \\
$20-30$
\end{tabular}

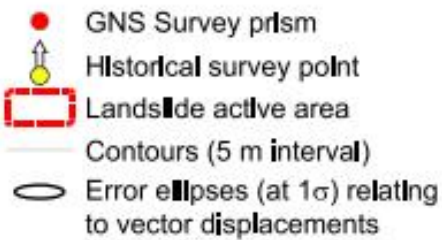

Fig. 6. The magnitude and vector bearing of horizontal surface displacement for: i) the historical survey marks; and ii) the prisms, located on the Taihape landslide. The historical displacement data is for the period 1984 to July 2015, and the prism data is for the period 1 July 2006 to 5 March 2011. Data shown for the historical survey marks are movement rates (velocities) and vector bearings (as arrows). For the prisms, the vector bearings, amount of movement (in $\mathrm{mm}$ ) and the associated error ellipses (at 95\% confidence) are shown for those prisms on the landslide with movement greater than the associated errors. 


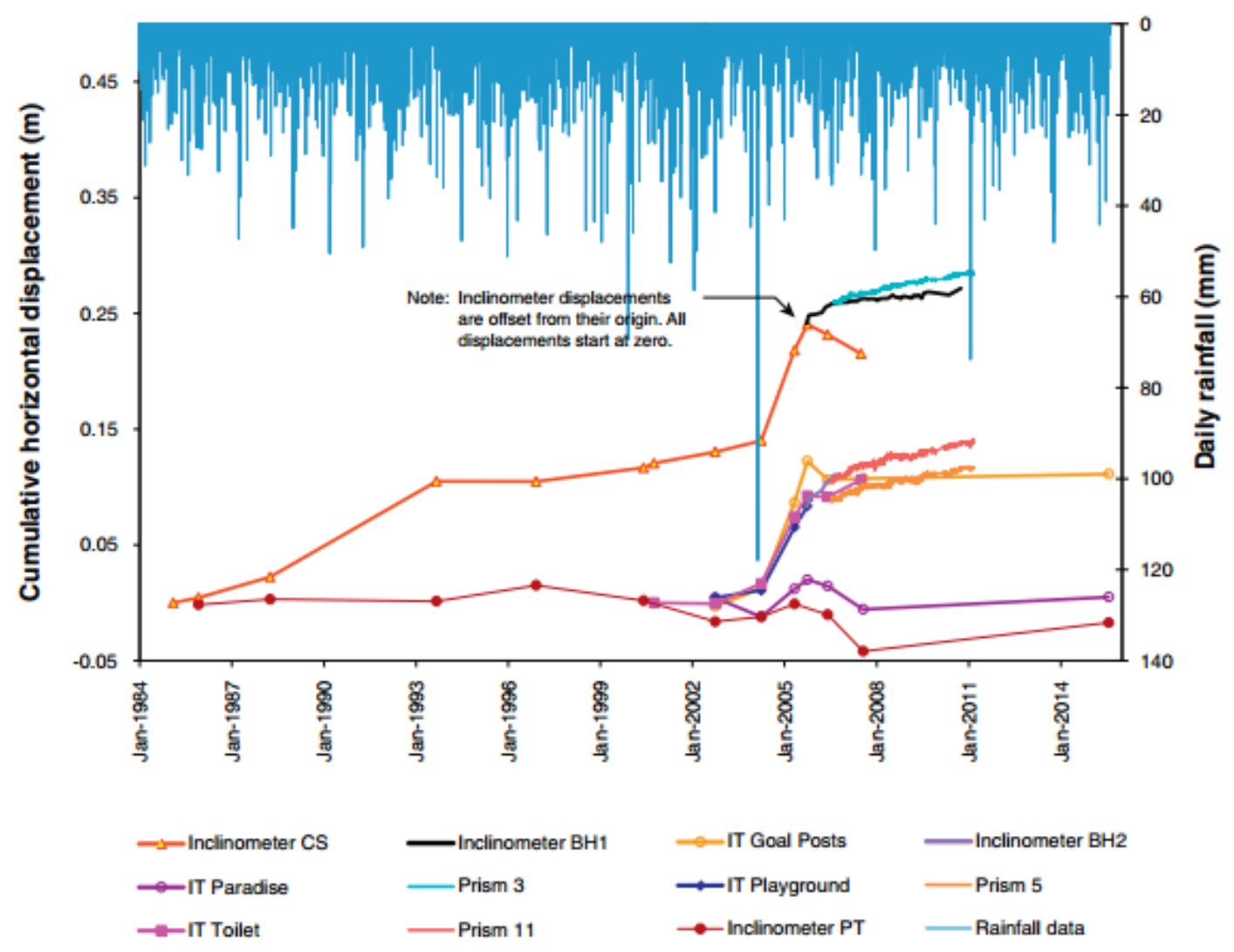

Fig. 7. Historical and recent surface and sub-surface cumulative displacement of the Taihape landslide, and the associated rainfall. Cumulative horizontal displacement of selected historical survey marks, prisms and inclinometers are plotted along their main vector bearings.

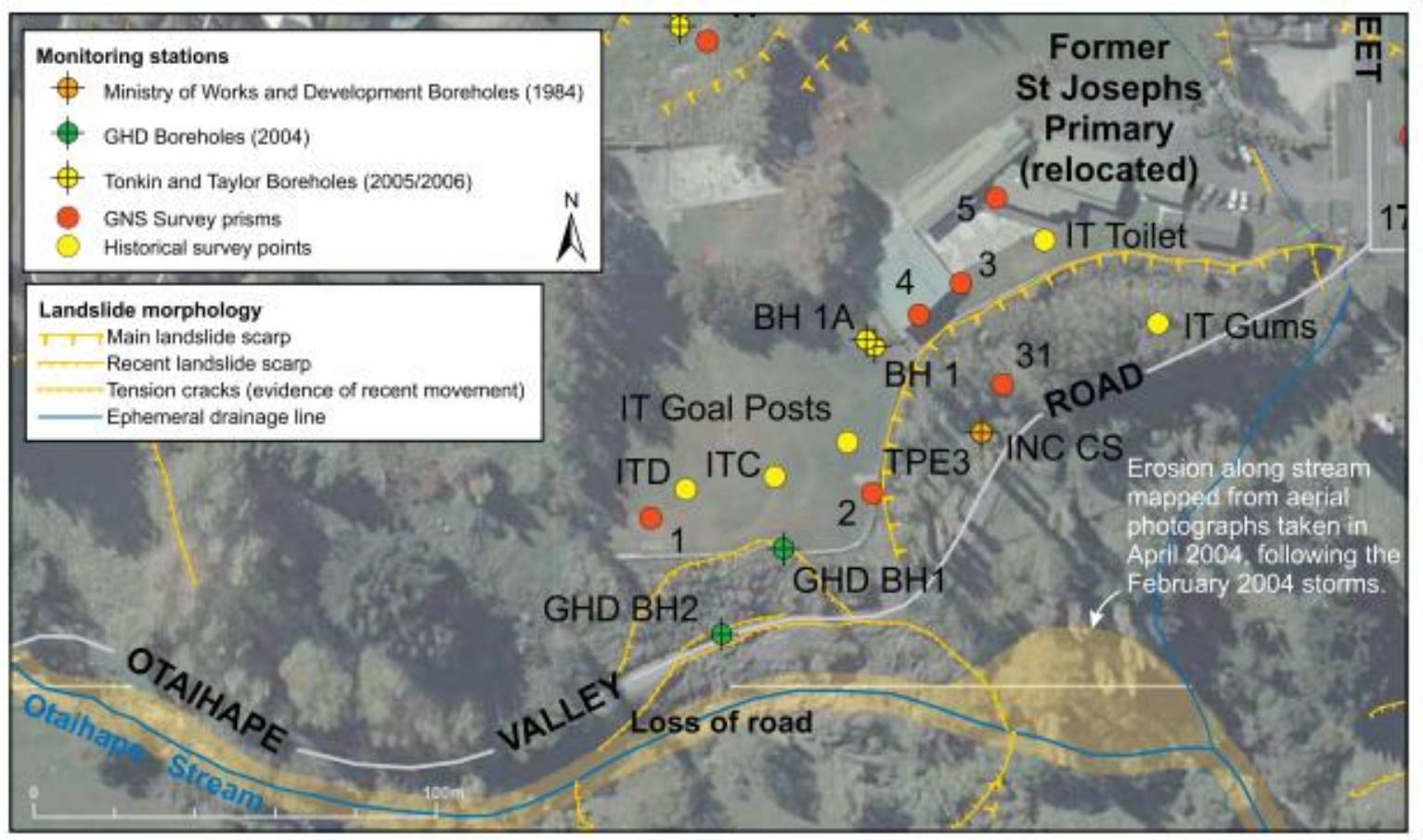

Fig. 8. Orthorectified aerial image dated April 2004 following the February 2004, Manawatu storm and flooding. The effects of the flooding and erosion along Otaihape Stream at the landslide toe can be seen in the form of tension cracks and the formation of a recent landslide scarp. 

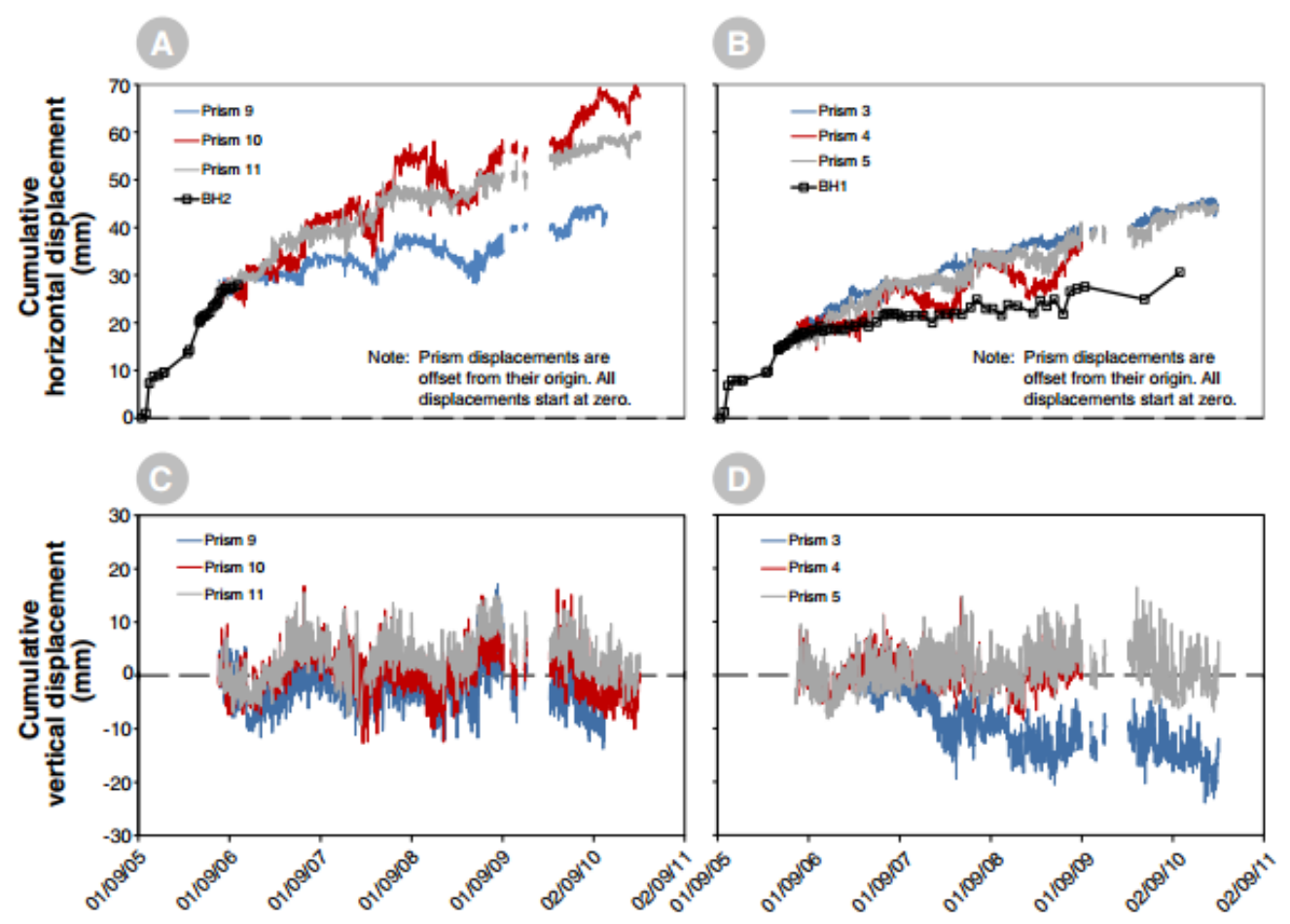

Fig. 9. Cumulative displacements recorded at the slip surface derived from the incremental inclinometer readings, and daily prism displacements, showing the cumulative horizontal and vertical displacements along the main vector bearings. A) and C) are prisms and inclinometers on the upper part of the active landslide. B) and D) are prisms and inclinometers on the lower part of the active landslide.
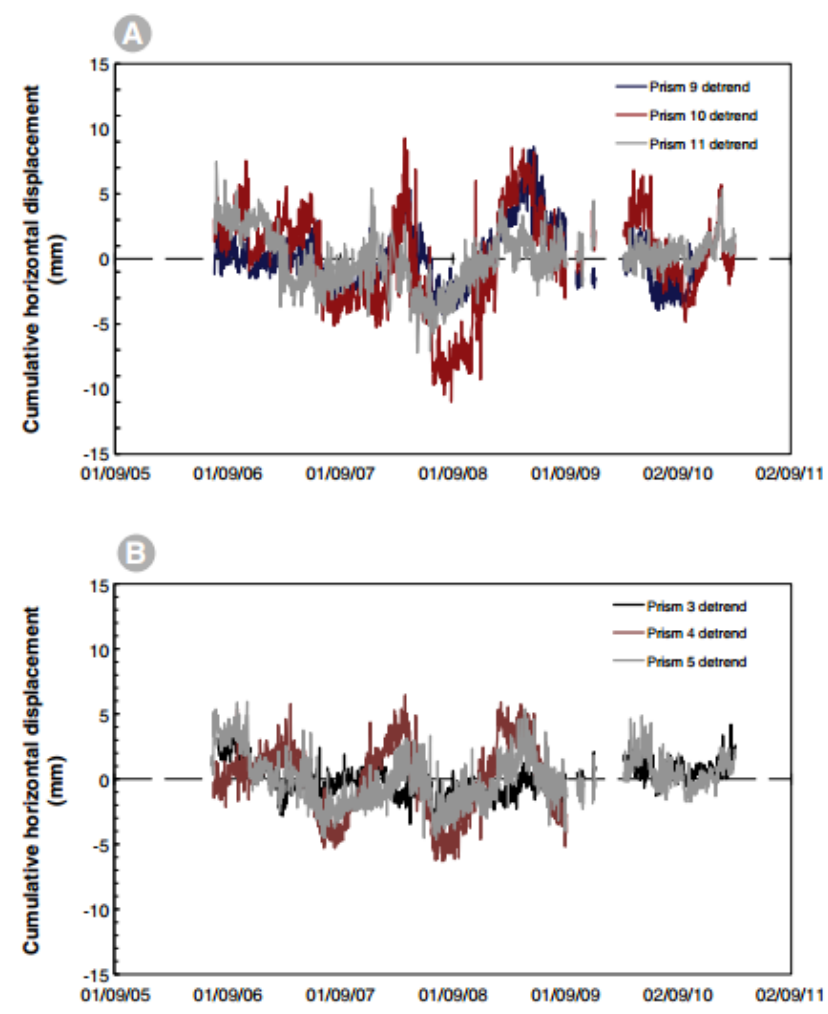

Fig. 10. Daily cumulative horizontal displacements of: A) prisms 9-11 on the upper landslide; B) prisms 3-5 on the lower landslide. Cumulative displacements are plotted along the vector bearings (Table 2). The cumulative 
displacements have been detrended by removing the linear trend of the extremely slow movement from the daily readings.
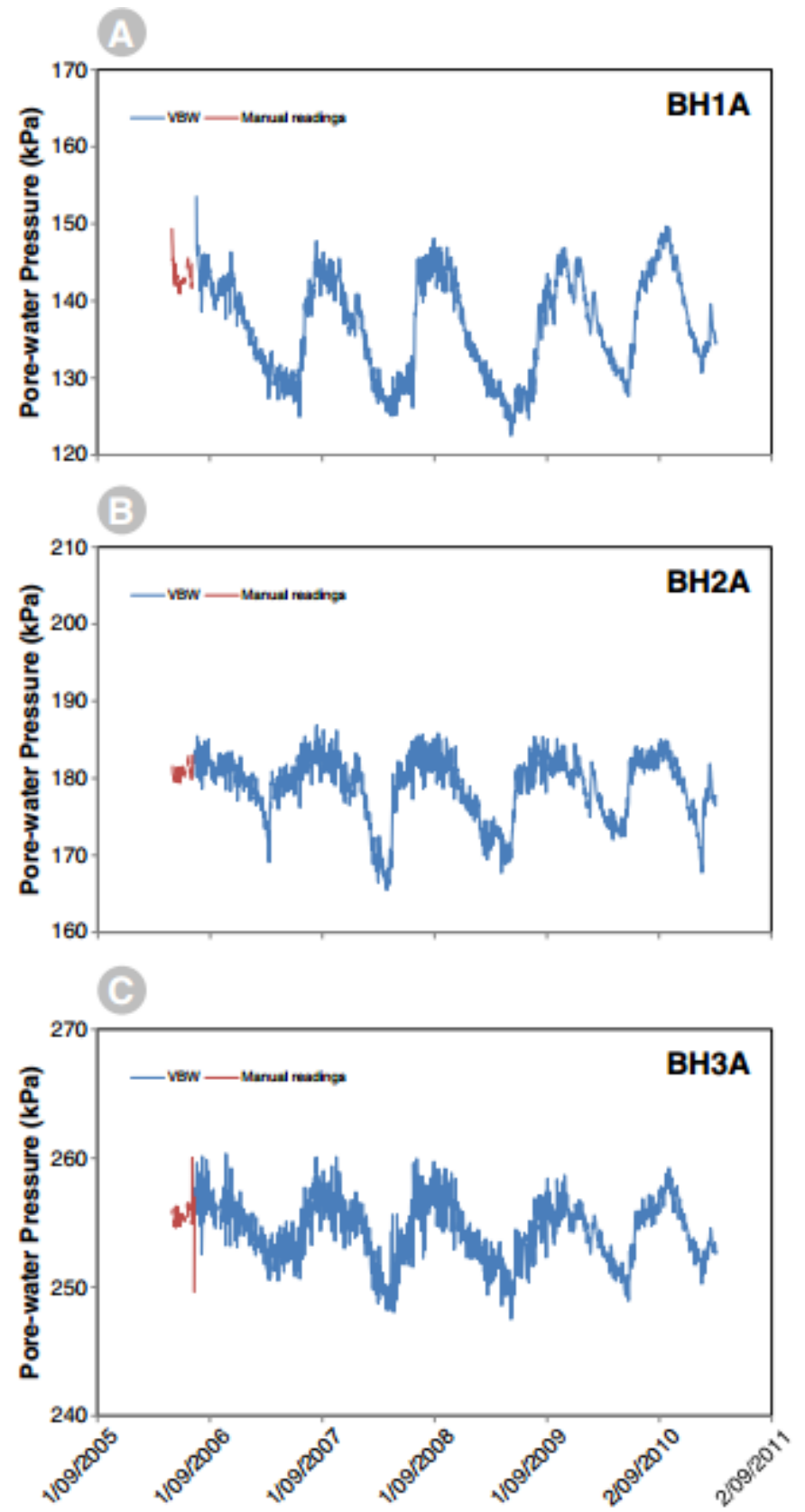

Fig. 11. Daily pore-water pressure measurements for piezometers $\mathrm{BH} 1 \mathrm{~A}, \mathrm{BH} 2 \mathrm{~A}$, and $\mathrm{BH} 3 \mathrm{~A}$. The data have been processed to remove the effects of barometric changes in pressure. 

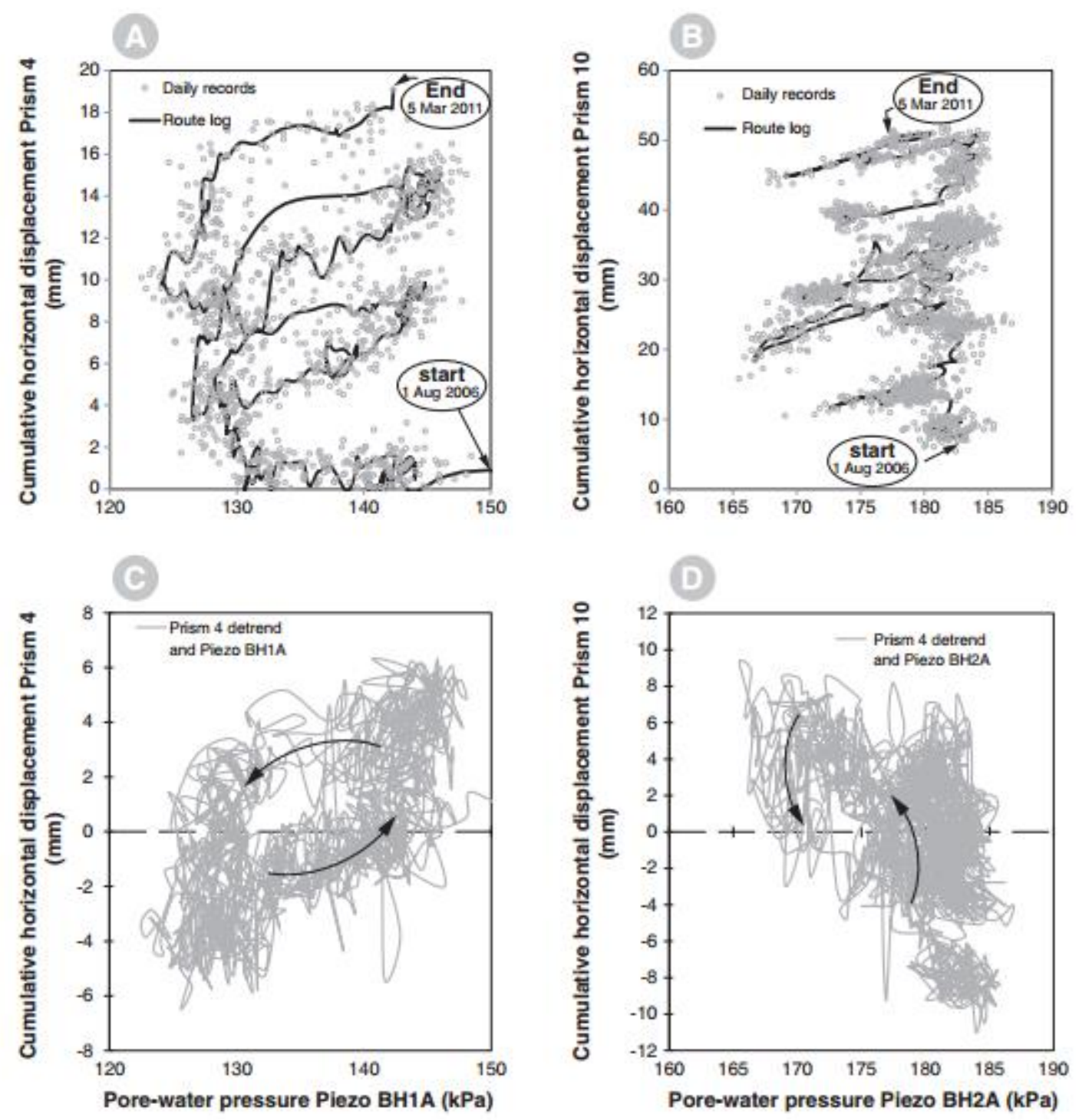

Fig. 12. Daily pore-water pressures recorded at piezometers $B H 1 A$ and $B H 2 A$ plotted against the corresponding daily cumulative horizontal displacements recorded at prisms 4 and 10 ( $A$ and $B$ ). Route logs are estimated based on a Gaussian smoothing kernel fitted to the daily time-series data and show the chronological order of the data, oldest to youngest. C) and D) are the same data processed by detrending the cumulative horizontal displacements by removing the trend of the extremely slow movement from the daily readings. 

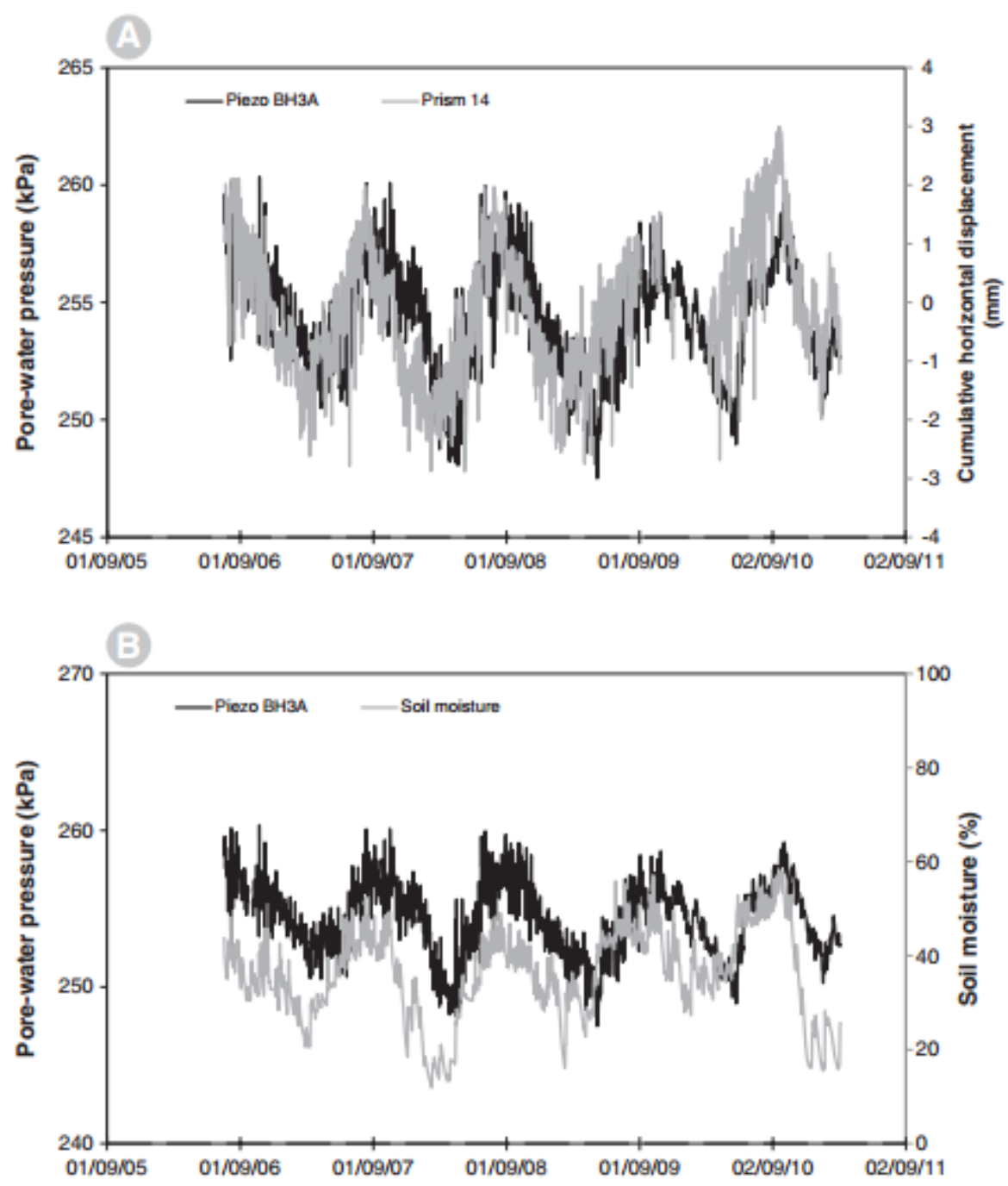

Fig. 13. A) Seasonal variations in cumulative horizontal surface displacements plotted against corresponding pore-water pressures for Prism 14, along vector bearing $189^{\circ}\left( \pm 30^{\circ}\right)$ located outside the active toe zone of the landslide (Fig. 3). B) Comparison of soil moisture and pore pressures trends recorded at depth within the landslide mass. Pore pressures are recorded at piezometer BH3A, located outside the active area of the landslide. Soil moisture is the mean daily measurements of two NIWA operated sites, their locations are shown on Fig. 1 (Lat: - 39.419, Long: 175.413; and Lat: - 39.337, Long: 174.305).

Differences in displacement vectors between the ground- and slide-surface in the lower part of the active landslide during the period of slower displacement were examined by fitting linear trend lines to the time-series data from prisms $3-5$ and the nearby inclinometer $\mathrm{BH} 1$ (Fig. 9A and B), for the period 20 July 2006-2 October 2010 (1535 days). Least-squares results (Table 3 ) show that prism movement at the surface was about double that recorded at the level of the inferred slide surface in the inclinometer. The mean horizontal basal sliding speed inferred from the inclinometer was $2( \pm 0.2) \mathrm{mm} /$ year and the mean horizontal surface speed inferred from the prisms was 5-6 $( \pm 0.1) \mathrm{mm} /$ year. The differences between the extremely slow rates of movement are statistically significant indicating that not all of the surface prism movement can be attributed to displacement at depth along the inferred landslide slide surface. Similar results are reported for the nearby Utiku landslide (Massey et 
al., 2013), where the difference between surface and sub-surface movement rates has been attributed to plastic deformation of the slide mass.

Thus, the net surface deformation at the Taihape landslide appears to be derived from two movement mechanisms, consisting of deep basal sliding on a clay seam, and internal plastic deformation the landslide mass. The relative rates of these two processes in terms of net downslope movement are approximately equal.

\subsection{Pore-water pressure and landslide displacement}

Manual measurement of water levels in borehole piezometers was carried out from 1 May 2006 to 10 July 2006. Manual measurement was replaced with automated (allowing higher temporal resolution) measurement of pore-water pressures from 10 July 2006 to 6 March 2012. The highest pore-water pressures were recorded at the piezometer tips in the central part of the landslide where piezometric head levels were artesian, and where surface seeps and springs have been observed. Piezometric head levels are close to the ground surface in most of the active part of the landslide, but decrease in the toe near Otaihape Stream. During the period of monitoring, all piezometers recorded seasonal cycles, with pore-water pressure decreasing in summer and autumn (December to May) and rising in winter and spring (June to November) (Fig. 11). The largest ranges (peak to peak) in the pore-water pressure time series were at $\mathrm{BH} 1 \mathrm{~A}$ and $\mathrm{BH} 2 \mathrm{~A}$, in the active toe zone of the landslide. These showed maximum fluctuations in piezometric head of about $15.7 \mathrm{kPa}(1.6 \mathrm{~m})$ above and $14.7 \mathrm{kPa}(1.5 \mathrm{~m})$ below mean values. Piezometers $\mathrm{BH} 3 \mathrm{~A}$ and $\mathrm{BH} 5 \mathrm{~A}$, in the central and upper part of the landslide, were similar to one another, with maximum fluctuations of about 8.8 $\mathrm{kPa}(0.9 \mathrm{~m})$ above and $9.8 \mathrm{kPa}(1.0 \mathrm{~m})$ below mean values. Mean piezometric head levels are shown on the cross section in Fig. 4.

The relationship between surface motion and basal landslide pore-water pressure were investigated by comparing selected historical movement, prism movement and inclinometer time series with the corresponding (in time) pore-water pressures. Pore-water pressure measurements from piezometers $\mathrm{BH} 1 \mathrm{~A}$ to $\mathrm{BH} 3 \mathrm{~A}$ when compared to the historical prism movements and those recorded by the inclinometers show that from 1 May 2006 to 20 July 2006, during the period of faster surface and subsurface movement, pore-water pressures were similar to those recorded after 20 July 2006, during the period of extremely slow movement. This suggests that the period of faster movement was not initiated by increased pore-water pressure at the slide surface. Surface movement and pore-water pressure after 20 July 2006, were compared for: i) prism 4 and the adjacent piezometer in BH1A on the lower part of the active landslide; and ii) prism 10 and the adjacent piezometer in $\mathrm{BH} 2 \mathrm{~A}$ on the upper part (Fig. 12). "Route logs" were calculated using a Gaussian smoothing kernel fitted to the daily time-series data, and shown in chronological order of the data, oldest to youngest. Prism 4 and piezometer BH1A (Fig. 12A) showed marked hysteresis, superimposed on a general increasing (downslope) cumulative movement trend. The positive (down slope) and negative (up slope) cyclic displacements correlate with seasonally 
rising and falling pore-water pressures, with each lasting about six months. The cycles of apparent increased displacement - with magnitudes of about $6 \mathrm{~mm}$ (in up- and down-slope directions) and changing about every six months - progressively, but slowly, move down slope, as there is a general increase in the cumulative horizontal movement of the prism over time. This underlying movement, at constant rate, was unaffected by changing porewater pressure. The results from prism 10 and piezometer $\mathrm{BH} 2 \mathrm{~A}$ were similar to those from prism 4 and piezometer $\mathrm{BH} 1 \mathrm{~A}$, as the time-series data also show marked hysteresis superimposed on a general down-slope movement of the prism. The hysteresis is shown more clearly in Fig. $12 \mathrm{C}$ and $\mathrm{D}$, where the prism cumulative movement time-series has been detrended by removing the linear extremely slow constant movement component. The arrows on the figures show the chronological order of the data. Prism 4 moves down slope during periods of increasing pore pressure, and up slope during periods of falling pore pressure, and prism 10 is similar, although not as clear as Prism 4. These trends suggest that the seasonal cyclic movements are indeed controlled by local effects at each of the prism sites and are unrelated to landslide movement. The same cyclic seasonal movement was identified in the movement time-series from prisms on stable parts of the landslide (e.g. prism 14, Fig. 13A), where the up- and down-slope seasonal prism motion results in no net change in position. Prism 14 showed displacement (peak to peak) of about $6 \mathrm{~mm} /$ year ( 3 $\mathrm{mm}$ in either direction). These cycles correlate well with pore pressure, with positive down slope (southward) movement during summer when pore pressure increases, and negative up slope (northward) motion when pore pressure decreases. However, no net change in prism position occurred over the monitoring period. Cyclic displacements were not detected at the slide surface by inclinometer $\mathrm{BH} 1$, where displacement was at a constant rate during the entire period, indicating that the measured seasonal changes in pore-water pressure did not trigger measurable change in the landslide's basal sliding rate. The cyclic motion is inferred to relate to near-surface (but deeper than the 1.5 to $2.0 \mathrm{~m}$ deep prism-anchor depth) ground shrinkage and swelling in response to seasonal soil-moisture change.

To further investigate the cyclic movement and its relationship to swelling and shrinkage, the time series of pore-water pressures from piezometer $\mathrm{BH} 3 \mathrm{~A}$ were plotted along with that of the mean daily soil moisture (Fig. 13B), recorded at two stations operated by the National Institute of Water and Atmospheric Research (NIWA) (locations are shown on Fig. 1). Although not recorded at the site, the soil-moisture measurements are from stations in similar terrain and climate to Taihape, and the time-series data from these different stations follow similar trends. Soil moisture is recorded at the two stations from volumetric measurements using Aquaflex ${ }^{\circledR}$ strips installed at a depth of $0.2 \mathrm{~m}$ below the surface (instrument ranges are $5-65 \%$ soil moisture with an accuracy of $\pm 2 \%$ ). Measurements are taken at hourly intervals and these have ben averaged over each 24-h period, for each station. When plotted together for the same time period, soil moisture and pore-water pressure follow the same seasonal trends, but soil moisture increases and decreases more rapidly than pore-water pressure. The data support our inference that the swelling and shrinkage shown by the prisms is related to seasonal changes in soil moisture. 


\subsection{Landslide stability}

Stability analyses were undertaken assuming that the landslide factor of safety was at 1.0 throughout the monitoring period, as motion recorded at the ground surface and at depth along the slide surface has been extremely slow and steady since the end of the period of faster displacement from April 2004 to 20 July 2006. As the rate of sliding since 20 July 2006, has not varied despite recorded pore-water pressure changes, mean piezometric levels recorded over the monitoring period were used for the initial stability analyses and to verify that the assumed material parameters for the slide surface clay were appropriate. For the slide-surface clay, the parameters of $\varphi r^{\prime}=9^{\circ}$ and $c^{\prime}=0 \mathrm{kPa}$ were adopted from the laboratory testing. Parameters adopted for the other landslide materials are shown in Table 1. Results indicate that the factor of safety of the active part of the landslide (Fig. 4, and corresponding to Zone A, Fig. 3) is about 1.0 when mean piezometric head levels are adopted (Table 4). Results from finite element modelling indicate that modelled mean horizontal displacements in the active part of the landslide, adopting the mean piezometric head levels, are less than $0.05 \mathrm{~m}$, similar to the amount of extremely slow movement recorded for the prisms at the surface. The results (shown in Table 4, for the different parts of the landslide shown in Fig. 4) also suggest that the factor of safety of the lower toe zone part of the active landslide is higher than the upper part, possibly indicating that the upper part is being buttressed by the lower part. Overall, the adopted material parameters, monitored pore pressures and calculated stresses appeared to be representative and capable of explaining the recorded extremely slow movements.

Table 4. Results from the stability analyses for section $A-A^{\prime}$. The factors of safety and shear strength reduction factors are for the toe zone (corresponding to Zone A, and the lower toe zone (Fig. 3 and Fig. 4).

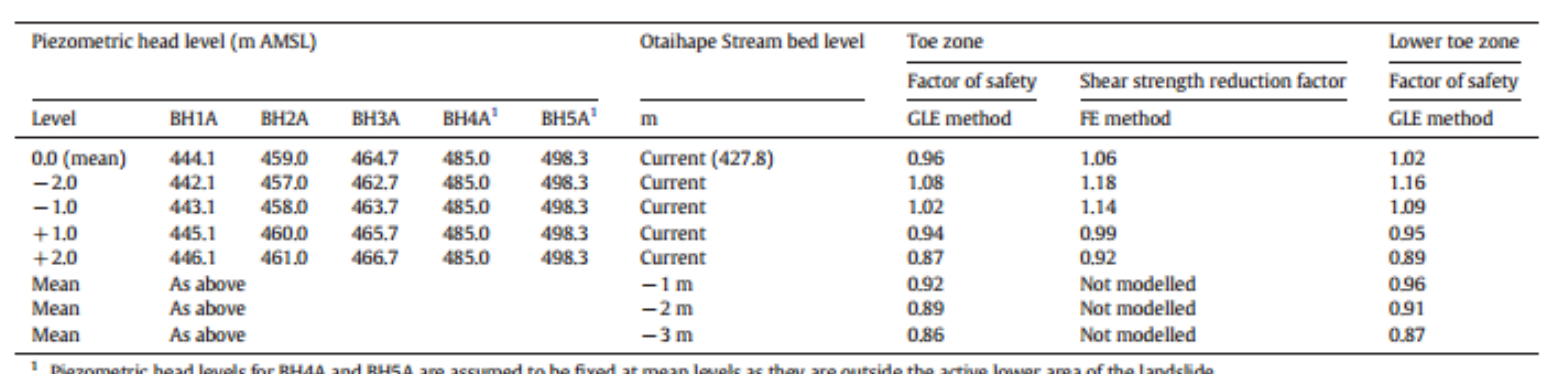

Piezometric head levels for BH4A and BHSA are assumed to be fixed at mean levels as they are outside the active lower area of the landslide.

The landslide sensitivity was assessed for changes in: i) the residual friction angle $\left(\varphi r^{\prime}\right)$ of the slide-surface clay; ii) changes in piezometric head (pore-water pressures) above the slide surface; and iii) toe unloading caused by drainage-line incision at Otaihape Stream. Results suggest that a $1^{\circ}$ change in $\varphi r^{\prime}$ causes a $10 \%$ change in the factor of safety, indicating that as expected, the active part of the landslide is sensitive to the frictional properties of the clay. However, the adopted parameters are well constrained in laboratory tests and have been tested by back analysis and are therefore thought to be representative. 
It is generally assumed that when the factor of safety drops below 1.0, landslide velocity increases with increasing pore-water pressure. As expected, the sensitivity analyses indicate that the factor of safety decreases in response to increases in piezometric head (Table 4). For a $1.0 \mathrm{~m}$ change in piezometric head, relative to mean levels, the factor of safety changes by approximately $5 \%$. Landslide velocity, however, remained steady throughout the monitoring period even though piezometric head levels fluctuated in the active part by about $\pm 1.5 \mathrm{~m}$ from the mean. Such variation represents about $8-10 \%$ change in modelled factor of safety. The absence of actual versus modelled response suggests that movement of the Taihape landslide is controlled by another factor, which given the confined nature of the landslide toe, is most likely to be fluvial erosion and reduction in toe support at Otaihape Stream. Otaihape Stream can influence the stability of the Taihape landslide through erosion of the landslide toe, leading to debutressing, as may have occurred during the storm in February 2004. Ongoing incision of the valley by the river could also lead to more gradual debutressing, given that the landslide slip surface is inferred to be below the current river bed level (Fig. 4 inset).

Sensitivity of the model to toe unloading therefore was assessed by modelling a systematic lowering of the bed of Otaihape Stream in $1.0 \mathrm{~m}$ increments (below the current level) whilst maintaining the current geometry of the stream cross section (Fig. 4 inset). Results suggest that each $1.0 \mathrm{~m}$ of vertical incision of the channel reduces the factor of safety by about $4 \%$, confirming that the landslide movement rate is likely to be sensitive to changes in the amount of toe support.

\section{Discussion}

Three deformation mechanisms explain the measured surface motion in the active part of the Taihape landslide: 1) basal sliding; 2) internal plastic deformation; and 3) near-surface seasonal shrinkage and swelling. The latter mechanism, which in some cases represented most of the detected motion, was unrelated to the net movement of the landslide mass, and was also evident in prism movements outside the active area of the landslide.

\subsection{Basal sliding and plastic deformation}

Basal sliding due to frictional slip (or alternatively viscous drag within the thin clay layer) was the assumed mechanism for the measured displacement along the inferred landslide slide surface and for an equal amount of ground-surface displacement parallel to the slide surface. This motion accounted for the largest recorded movements. Basal sliding mechanisms in these types of landslide are controlled primarily by factors that alter the stress state of the landslide mass. These are most frequently caused by changes in porewater pressure (e.g.: Leroueil et al., 1996, Van Asch et al., 2009 and Zangerl et al., 2010), or 
more rarely by seismic disturbance, toe excavation (unloading), head loading and even atmospheric tides (Schulz et al. 2009). Although the monitored movement of those prisms on slide blocks within the active part of the landslide were predominantly horizontal, two prisms near slide-block boundaries showed vertical movements and rotation indicating that patterns of surface movement vary between different parts of the landslide, and that different geomorphological features can be associated with particular patterns of movement, e.g., grabens associated with vertical and rotational movement, whilst prism within slide-blocks tend to show predominantly horizontal translational motion.

The main period of monitored more rapid movement (April 2004 to July 2006) followed two months after a 100-year storm in which there was significant landslide toe erosion, suggesting that resistance at the toe may be a major movement-controlling factor. This is supported by the observation that the period of faster displacement lasted for more than two years when pore pressures would have varied seasonally, as shown by the monitored pore-water pressures. These findings are similar to those of Ferrari et al. (2010), who showed that landslide movement could be controlled by erosion and movement of a "foot block" at the toe of the landslide, which regulates the movement of the larger landslide. Frictional basal sliding leading to permanent surface displacement occurred at an extremely slow rate over the remainder of the monitoring period. This extremely slow movement occurred at a constant rate that did not change with changes in pore-water pressure or any other monitored factor. During this period, surface displacements were about double those at the base, and consequently about half of the surface displacement was inferred to result from non-recoverable internal (plastic) deformation within the landslide mass.

\subsection{Seasonal-shrinkage and swelling}

The high-resolution prism monitoring detected seasonal cyclic movements of prisms on and beyond the active portion of the landslide. Although large enough to be measured, this motion is not considered to be landslide movement, as it did not lead to permanent displacement of the landslide mass. The seasonal cyclic movement was synchronous with changes in soil moisture and pore pressure, suggesting that it may be a shrink/swell process associated with wetting and recharge of groundwater during the winter months, and soil shrinkage during the dryer summer months. This mechanism may be similar to that reported by Leung and $\mathrm{Ng}$ (2012). Seasonal cyclic movement may have been occurring during the earlier period of faster movement, but the low frequency and precision of the earlier monitoring would not have detected it. Even during monitoring at high precision and frequency, cyclic vertical motion was much less well resolved in the prism time series than was the cyclic horizontal motion, possibly because vertical angular measurements are much more affected by atmospheric refraction than are horizontal angular measurements. 


\section{Conclusions}

The Taihape landslide can be classified as a deep-seated translational rockslide. During the monitoring period, surface movement can be classified as being extremely slow, but the period included intervals of faster and slower landslide movement due to basal sliding and distributed internal plastic deformation, with additional seasonal cyclic movement unrelated to landslide movement. The fastest monitored landslide displacement, as measured on the surface and at depth, occurred between April 2004 and July 2006. Stability modelling suggested that this displacement period might have been a delayed response to toe erosion during a flood in February 2004, which had a return period of about 100 years.

Monitoring data from the Taihape landslide suggests that extremely slow movement occurred at a constant rate and involved both sliding on the inferred slide surface, and distributed plastic deformation within the slide mass, supplemented by localised subsidence of slide blocks into grabens along internal planes of weakness. This movement accounted for surface motion of about $10 \mathrm{~mm} /$ year. Since the rate did not vary significantly over time, there was no correlation with pore-water pressure or with any other monitored variable. An annual cyclic surface motion believed to be from shrinkage and swelling had a magnitude of about $\pm 20 \mathrm{~mm}$ in the horizontal (+ 10 and $-10 \mathrm{~mm} /$ year, averaging $0 \mathrm{~mm} /$ year) with both downslope and upslope motion causing no net annual change in prism position. On the active portion of the landslide, this was superimposed on the constant rate displacement. Seasonal cyclic displacements were synchronous with cyclic changes in soil moisture and pore-water pressure. The cyclic surface motion was not detected at the basal slide surface, implying that it related to a near-surface shrink/swell processes probably associated with wetting and recharge of soil moisture/groundwater during the wetter winter months and soil shrinkage during the dryer summer months.

The high-temporal and spatial frequency of the monitoring and the measurement precision of the instruments have allowed such complex movement patterns to be revealed and compared against factors that may cause them. The ability to create such high-resolution data sets allows better understanding of the movement patterns of such landslides.

\section{Acknowledgments}

The authors acknowledge: the New Zealand Natural Hazard Research Platform for funding the research; the GeoNet project for funding monitoring equipment and the GeoNet team for installing and maintaining equipment. We also thank the Earthquake Commission for funding subsurface geotechnical investigations and Kate Williams and Nick Rogers (Tonkin and Taylor Ltd.) for useful discussions during this project. Geotechnics Ltd. carried out the inclinometer surveys. Petley was funded by the International Landslide Centre at Durham University, UK and by two anonymous benefactors to Durham University. The authors would also like to thank the anonymous peer reviewers for their constructive comments, which have helped to improve the manuscript. 


\section{References}

Allison and Brunsden, 1990 R.J. Allison, D. Brunsden Some mudslide movement patterns Earth Surf. Process. Landf., 15 (4) (1990), pp. 297-311

Carey, 2011 J. Carey The Progressive Development and Post-Failure Behaviour of deepSeated Landslide Complexes Doctoral thesis Durham University, UK (2011)

Corominas et al., 2005 J. Corominas, J. Moya, A. Ledesma, A. Lloret, J.A. Gili Prediction of ground displacements and velocities from groundwater level changes at the Vallcebre landslide (Eastern Pyrenees, Spain) Landslides, 2 (2005), pp. 83-96

Cotton, 1944 C.A. Cotton Volcanoes as landscape forms Whitcombe and Tombs, Christchurch (1944), p. 415

Cruden and Varnes, 1996 D.M. Cruden, D.J. Varnes Landslide types and processes ,in: K.A. Turner, R.L. Schuster (Eds.), Landslides: Investigation and Mitigation, Special Report 247, Transportation Research Board, Washington (1996), pp. 36-75

Dawson et al., 1999 E.M. Dawson, W.H. Roth, A. Drescher Slope stability analysis of by strength reduction Geotechnique, 122 (6) (1999), pp. 835-840

Dellow et al., 2005 G.D. Dellow, M.J. McSaveney, M.W. Stirling, K.R. Berryman A Probabilistic Landslide Hazard Model for New Zealand, in: J.R. Pettinga, A.M. Wandres (Eds.), Geological Society of New Zealand 50th Annual Conference, 28 November to 1 December 2005, Geological Society of New Zealand Miscellaneous Publication, 119A, , programme \& abstracts, Kaikoura (2005), p. 24

Ferrari et al., 2010 A. Ferrari, A. Ledesma, D.A. Gonzalez, J. Corominas Effects of the foot evolution on the behaviour of slow-moving landslides Engineering Geology. (2010) http://dx.doi.org/10.1016/j.enggeo.2010.11.001

Geokon, 2005 Geokon Model 4500 vibrating wire piezometer. (data sheet) http://www.geokon.com/products/datasheets/4500.pdf (2005)

Gillespie, 1971 K.H. Gillespie Consultation on landslide, Kaka Road, Taihape. Brickell, Moss, Rankine and Hill, Consulting Engineers Consultancy Report Number. 5688 (1971) (April 30, 1971)

Horizons Regional Council, 2004 Horizons Regional Council Storm, civil emergency - Storm and flood report (2004) February 2004. Report No. 2004/EXT/591

Kilsby, 2007 C. Kilsby An Engineering Geological Appraisal of the Utiku Landslide, North Island, New Zealand M.Sc. Thesis University of Portsmouth (2007), pp. 19-27

Lee et al., 2012 Lee, J.M., Bland, K.J., Townsend, D.B., Kamp, P.J.J. (comp). 2012. Geology of the Hawke's Bay Area. Institute of Geological and Nuclear Sciences 1:250,000 geological map 8. Lower Hutt. Institute of Geological and Nuclear Sciences Limited.

Leroueil et al., 1996 S. Leroueil, J. Locat, J. Vaunat, L. Picarelli, R. Faure, in: K. Senneset (Ed.), Geotechnical Characterisation of Slope Movements. Proceedings of the Seventh 
International Symposium on Landslides, 1, Rotterdam, Trondheim, Norway, Balkema (1996), pp. 53-74

Leung and Ng, 2012 A.K. Leung, C.W.W. Ng Seasonal movement and groundwater flow mechanism in an unsaturated saprolitic hillslope Landslides (2012)

http://dx.doi.org/10.1007/s10346-012-0343-7

Litchfield et al., 2007 N. Litchfield, S. Ellis, K. Berrymen, A. Nicol Insights into subductionrelated uplift along the Hikurangi margin, New Zealand, using numerical modelling J. Geophys. Res., 112 (2007)

Massey, 2010 C.I. Massey The Dynamics of Reactivated Landslides: Utiku and Taihape, North Island, New Zealand PhD Thesis Durham University (2010) (http://etheses.dur.ac.uk/587/)

Massey et al., 2013 C.I. Massey, D.N. Petley, M.J. McSaveney Patterns of movement in reactivated landslides Eng. Geol., 159 (2013), pp. 1-19

http://dx.doi.org/10.1016/j.enggeo.2013.03.011

Matsuura et al., 2008 S. Matsuura, S. Asano, T. Okamoto Relationship between rain and/or meltwater, pore-water pressure and displacement of a reactivated landslide Eng. Geol., 101 (2008), pp. 49-59

Morgenstern and Price, 1965 N.R. Morgenstern, V.E. Price The analysis of the stability of general slip surfaces Geotechnique, 15 (1) (1965), pp. 79-93

Mountjoy and Pettinga, 2006 J. Mountjoy, J.R. Pettinga Controls on large deep-seated landslides in soft rock terrain Rock Mass Defects and Seismic Triggering. Earthquakes and Urban Developments, Proceedings of the New Zealand Geotechnical Society 2006 Symposium, Proceedings of Technical Groups. 31, IPENZ (2006)

Ng and Petley, 2009 K.-Y. Ng, D.N. Petley A process approach towards landslide risk management in Hong Kong Q. J. Eng. Geol. Hydrogeol., 42 (4) (2009), pp. 487-498

Picarelli, 2007 L. Picarelli Considerations about the mechanics of slow active landslides in clay K. Sassa, H. Fukuoka, F. Wang, G. Wang (Eds.), Progress in Landslide Science (2007), pp. 27-57 Chapter 3

Pillans, 1986 B. Pillans A late Quaternary uplift map for North Island, New Zealand Trans. Roy. Soc. NZ Bull., 24 (1986), pp. 409-417

Pulford and Stern, 2004 A. Pulford, T. Stern Pliocene exhumation and landscape evolution of central North Island, New Zealand: the role of the upper mantle J. Geophys. Res., 109 (2004), Article F01016 http://dx.doi.org/10.1029/2003JF000046

Read, 2007 S.A.L. Read, P.J. Miller Characterisation and classification of New Zealand Tertiary age sedimentary soft rocks Bridge Design and Research Seminar, Road Engineering in Soft Rock Materials. RRU Bulletin 84, Vol. 4 (1990), pp. 1-25

A.G. Reyes Petrological study of selected Taihape landslide rock samples The Institute of Geological and Nuclear Sciences Science Report 2007/32 (2007) Reyes, 2007 
A.G. Reyes Petrological study of selected Taihape landslide rock samples The Institute of Geological and Nuclear Science, Science Report, 2007/32 (2007)

Schulz et al., 2009 W.H. Schulz, J.W. Kean, G. Wang Landslide movement in Southwest Colorado triggered by atmospheric tides Nat. Geosci., 2 (2009), pp. 863-866

Skempton, 1985 A.W. Skempton Residual strength of clays in landslide, folded strata and the laboratory Geotechnique, 35 (1) (1985), pp. 3-18

Indicator, 2005 Slope Indicator Digitilt inclinometer probe. Data sheet. Durham geo slope indicator http://www.slopeindicator.com/pdf/digitilt-vertical-inclinometer-probedatasheet.pdf (2005)

Stout, 1977 Stout, M. L. 1977. The Utiku landslide, North Island, New Zealand. Geological Society of America, Rev. Eng. Geol. III. pp 171 to 184.

Te Punga, 1952 M.T. Te Punga The Geology of Rangitikei Valley New Zealand Geological Survey. Memo, No. 8 (1952)

Thiebes, 2012 Thiebes, B. 2012. Landslide analysis and early warning systems. Local and regional case study in the Swabian Alb, Germany. Doctoral thesis accepted by the University of Vienna, Austria.

Thompson, 1982 R.C. Thompson Relationship of geology to slope failures in soft rocks of the Taihape-Mangweka area, Central North Island, New Zealand PhD Thesis University of Auckland (1982)

Van Asch et al., 2009 W.J. Van Asch, J.P. Malet, T.A. Bogaard The effect of groundwater fluctuations on the velocity pattern of slow-moving landslides Nat. Hazards Earth Syst. Sci., 9 (2009), pp. 739-749

Zangerl et al., 2010 C. Zangerl, E. Eberhardt, S. Perzlmaier Kinematic behaviour and velocity characteristics of a complex deep-seated crystalline rockslide system in relation to its interaction with a dam reservoir Eng. Geol., 112 (2010), pp. 53-67 